\title{
New species and new records of terrestrial isopods (Crustacea, Isopoda, Oniscidea) of the families Philosciidae and Scleropactidae from Brazilian caves
}

\author{
Ivanklin Soares CAMPOS-FILHO ${ }^{1, *}$, Camile Sorbo FERNANDES ${ }^{2}$, Giovanna Monticelli \\ CARDOSO $^{3}$, Maria Elina BICHUETTE ${ }^{4}$, José Otávio AGUIAR ${ }^{5} \&$ Stefano TAITI ${ }^{6}$ \\ ${ }^{1,5}$ Universidade Federal de Campina Grande, Programa de Pós-Graduação \\ em Engenharia e Gestão de Recursos Naturais, Av. Aprígio Veloso, 882, \\ Bairro Universitário, 58429-140 Campina Grande, Paraíba, Brazil. \\ ${ }^{2,4}$ Universidade Federal de São Carlos, Departamento de Ecologia e Biologia Evolutiva, \\ Rodovia Washington Luis, Km 235, 13565-905 São Carlos, São Paulo, Brazil. \\ ${ }^{3}$ Universidade Federal do Rio Grande do Sul, Programa de Pós-Graduação em Biologia Animal, \\ Departamento de Zoologia, Laboratório de Carcinologia, Av. Bento Gonçalves, \\ 9500, Agronomia, 91510-979 Porto Alegre, Rio Grande do Sul, Brazil. \\ ${ }^{6}$ Istituto di Ricerca sugli Ecosistemi Terrestri, Consiglio Nazionale delle Ricerche, \\ Via Madonna del Piano 10, 50019 Sesto Fiorentino (Florence), Italy. \\ ${ }^{6}$ Museo di Storia Naturale, Sezione di Zoologia "La Specola", Via Romana 17, 50125 Florence, Italy.
}

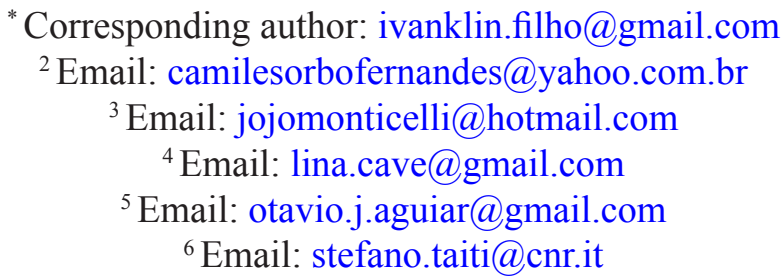

\footnotetext{
${ }^{1}$ urn:1sid:zoobank.org:author:C752F864-3C84-4AF4-9EDA-4D1AF464D615

${ }^{2}$ urn:lsid:zoobank.org:author:C8246067-8235-4981-87D8-56FD9C43FDC2

${ }^{3}$ urn:lsid:zoobank.org:author:C829E5B7-B87E-4C4A-B88E-D5FE377AE60B

${ }^{4}$ urn:lsid:zoobank.org:author:7B740115-BCA0-4711-8C9D-CD014FD3122B

${ }^{5}$ urn:1sid:zoobank.org:author:8D91D781-EF49-42CC-B7AE-12789CB1CD71

${ }^{6}$ urn:Isid:zoobank.org:author:62E97059-6AE5-4984-9ABB-7FB6F7358BD6
}

\begin{abstract}
After the examination of a large collection of Oniscidea from caves in the Brazilian states of Bahia, Minas Gerais, Pará, Sergipe and São Paulo, 12 species were recognized in the families Philosciidae and Scleropactidae. Four new species are described: Alboscia jotajota sp. nov. from the Açungui group; Androdeloscia akuanduba sp. nov. and Amazoniscus spica sp. nov. from the Carajás Formation; and Metaprosekia igatuensis sp. nov. from the Quadrilátero Ferrífero karst region. In addition, Atlantoscia inflata, Benthana longicornis, B. olfersii, B. picta and Paratlantoscia rubromarginata (Philosciidae) are recorded from Brazilian caves for the first time; and Benthana iporangensis, B. taeniata and Circoniscus bezzii (Scleropactidae) have the knowledge of their distribution extended to cave habitats.
\end{abstract}


Keywords. Subterranean environment, Açungui group, Carajás Formation, Quadrilátero Ferrífero karst region, Neotropical.

Campos-Filho I.S., Fernandes C.S., Cardoso G.M., Bichuette M.E., Aguiar J.O. \& Taiti S. 2020. New species and new records of terrestrial isopods (Crustacea, Isopoda, Oniscidea) of the families Philosciidae and Scleropactidae from Brazilian caves. European Journal of Taxonomy 606: 1-38. https://doi.org/10.5852/ejt.2020.606

\section{Introduction}

South America comprises twelve countries and four dependencies, with approximately 17.8 million $\mathrm{km}^{2}$. Despite this large extension, only $2 \%$ of its territory has suitable lithology for the development of karstic systems (Auler 2004, 2017). In the 19 karst areas of Brazil ca 18000 caves are presently known (18\% of the total estimated cave number, ca 100 000) (Auler 2002; CECAV 2015; Rubbioli et al. 2019). Most of these caves occur in carbonatic rocks, where the largest subterranean systems have been developed, and some in siliciclastic rocks. Moreover, non-karst cavities may occur in ferruginous and other types of rocks and sediments (Sallun Filho \& Karmann 2012).

Terrestrial isopods (Oniscidea) are one of the unique lineages among crustaceans completely adapted to a terrestrial way of life (Hornung 2011; Richardson \& Araujo 2015; Taiti 2018). To date, more than 3700 species in 38 families are known worldwide (Javidkar et al. 2015; Sfenthourakis \& Taiti 2015).

The Oniscidea are among the most important macrofauna components in tropical habitats, including the Neotropical region (Leistikow 1999, 2001; Schmidt 2003, 2007; Campos-Filho et al. 2015a, 2017a; WoRMS 2019), where Philosciidae Kinahan, 1857 and Scleropactidae Verhoeff, 1938 are most abundant. To date, the Philosciidae comprise more than 500 species in 107 genera worldwide and the Scleropactidae include more than 100 species in 26 genera (Sfenthourakis \& Taiti 2015; LópezOrozco et al. 2016, 2017; Campos-Filho et al. 2018a; Carpio-Díaz et al. 2018; Taiti et al. 2018).

Among the invertebrates collected in cave environments, the Oniscidea are one of the most representative groups (Trajano \& Bichuette 2010; Gallão \& Bichuette 2012, 2018; Silva \& Ferreira 2015; Fernandes et al.2019), and their presence is strictly related to the abiotic and biotic conditions of these environments, i.e., humidity, temperature stability and the variety of substrates such as guano and organic matter carried into the cave (Fernandes et al. 2019). To date, more than 300 troglobiotic species in 16 families of terrestrial isopods are known, mostly from the northern part of the globe (Taiti \& Gruber 2008; Taiti \& Xue 2012; Campos-Filho et al. 2014, 2016; Taiti 2014; Reboleira et al. 2015; Taiti \& Montesanto 2018). In Brazil, more than 190 species of terrestrial isopods are known (Campos-Filho et al. 2018a, 2018b, 2019), of which 16 species are considered to be troglobionts (see Campos-Filho et al. 2018a, 2019; Fernandes et al. 2019).

In this paper, four new species of terrestrial isopods are described in the families Philosciidae and Scleropactidae from Brazilian caves. In addition, Benthana longicornis Verhoeff, 1941, B. olfersii (Brandt, 1833), B. picta (Brandt, 1833) and Paratlantoscia rubromarginata Araujo \& Leistikow, 1999 are recorded for the first time in cave habitats, and Benthana iporangensis Lima \& Serejo, 1993, B. taeniata Araujo \& Buckup, 1994 and Circoniscus bezzii Arcangeli, 1931 have the knowledge of their distributions extended to the subterranean environment.

\section{Material and methods}

Specimens were collected by active search and stored in $75 \%$ ethanol. Identifications and descriptions are based on morphological characters with the aid of micropreparations. For each new species, details on the type material, the description, etymology and remarks are given. For already known species, 
distribution and remarks, if necessary, are given. The synonymic list includes the original publication and only citations of records from Brazil. The complete references are available in Schmalfuss (2003) and Campos-Filho et al. (2018a). The illustrations of the habitus were obtained with the aid of a Sony DSC-W800 camera mounted on a Biofocus SQF-L-BI microscope. The appendages were illustrated with the aid of a camera lucida mounted on a $\mathrm{CH} 2$ Olympus microscope. Coordinates of the 'noduli laterales' were obtained and illustrated as described in Vandel (1962). The final illustrations were prepared using the software GIMP (ver. 2.8) with the method proposed by Montesanto $(2015,2016)$. The material is deposited in the collections of the Laboratório de Estudos Subterrâneos, Universidade Federal de São Carlos, São Carlos (LES), and Museu de Zoologia, Universidade de São Paulo (MZUSP), both in the state of São Paulo, Brazil.

\section{Study Area}

Our study covered a large latitudinal extension of the Brazilian territory. The characteristics of climate, vegetation, geomorphology, biogeographic history and potential threats to the hypogean environments for each region are given below.

\section{Alto Ribeira karst area, state of São Paulo, southeastern Brazil}

The Alto Ribeira karst area (Fig. 1A-B) is one of the largest fragments of the Brazilian Atlantic forest protected by law and under Conservation Units. The presence of hydrographic basins, forests and a large number of caves in the region represents strategic strongholds of the endemic epigean and hypogean biodiversity (SEMA 1997). The region has the Atlantic forest as the main vegetation domain (Ab'Saber 1977). According to Koppen's criteria (Alvares et al. 2013), the climate of the region is subtropical humid without a dry season, where lowlands and highlands have hot summers (Cfa) and temperate summers (Cfb), respectively. Our samples were collected in caves under the limits of two Conservation Units of Integral Protection, Parque Estadual Intervales (PEI) and Parque Estadual Turístico do Alto Ribeira (PETAR). The PEI covers the territories of Iporanga, Eldorado Paulista, Sete Barras and Ribeirão Grande, and is bordered by other Conservation Units, including PETAR, while PETAR covers the municipalities of Apiaí and Iporanga (SEMA 2006; Sallun \& Sallun Filho 2009). Both parks have several different cave systems in Açungui group rocks, with Precambrian metasedimentary limestone outcrops discontinuously, intercalated with insoluble rocks (Karmann \& Sánchez 1979). Currently, both parks face problems with uncontrolled tourism, land conflicts and pollution of subterranean drainage due to illegal mining and agriculture (Gallão \& Bichuette 2018).

\section{Presidente Olegário, state of Minas Gerais, southeastern Brazil}

The karst area of Presidente Olegário (Fig. 1C-D) municipality is inserted in the northeastern portion of the state of Minas Gerais. This is a limestone area of the Bambuí geomorphologic unit with more than 200 recorded caves. The Paracatu hydrographic sub-basin, southern São Francisco River Basin, irrigates the region (Auler et al. 2001). According to Köppen's criteria (Alvares et al. 2013), the climate of the region is humid subtropical with dry winters and hot summers (Cwa). The landscape was originally covered by the Cerrado domain (Ab'Saber 1977), with transition spots of Seasonal Semideciduous Forest (Atlantic rainforest) near the limestone outcrops where caves are inserted. To date, agriculture and cattle farming are present in the region, culminating in extensive deforestation, including areas near the caves. Moreover, it is a region threatened by the construction of small hydroelectric centers (Gallão \& Bichuette 2018).

\section{Itabirito, state of Minas Gerais, southeastern Brazil}

Itabirito is part of the metropolitan sprawl of Belo Horizonte, capital of the state of Minas Gerais, southeastern Brazil. Its landscape is part of the Cerrado Domain with transition spots of Seasonal Semideciduous Forest. According to Köppen's criteria (Alvares et al. 2013), the climate of the region is humid subtropical with dry winters and hot summers (Cwa). The caves in this region occur in iron ore 
rocks of the Quadrilátero Ferrífero, a speleological unit of great interest to mining companies. Due to this lithology, the caves present several small spaces and more connections with surface environments than limestone caves (Bichuette et al. 2015; Ferreira et al. 2015). Biospeological studies in iron ore caves only started a few years ago, but a rich and diverse fauna has already been described, even in caves with little linear development (Bichuette et al. 2015; Ferreira et al. 2015). Itabirito is near several mining areas, and its subterranean environments and fauna suffer continuously from the impacts of ore exploitation.
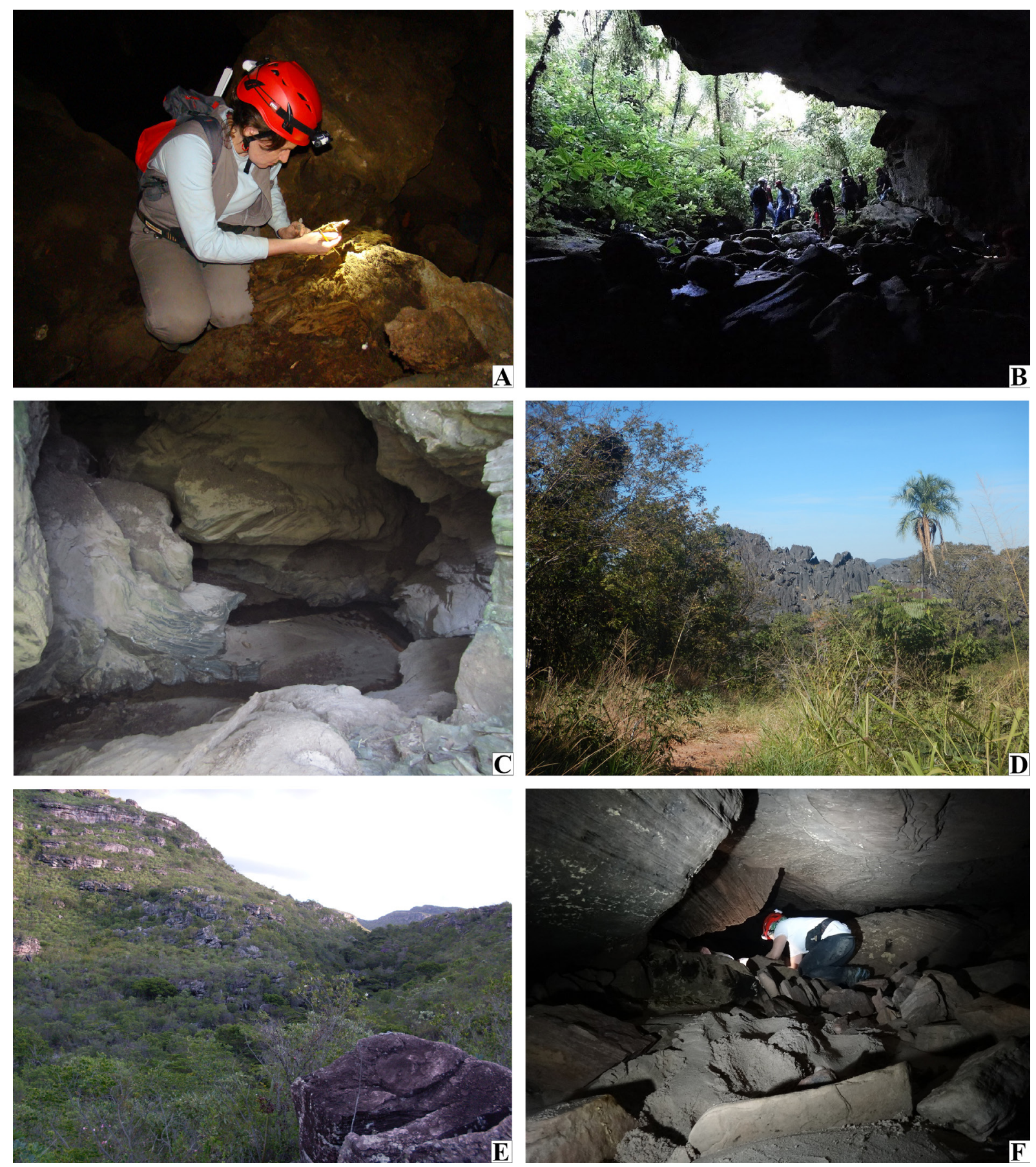

Fig. 1. Study areas. A. Ressurgência das Areias de Água Quente, PETAR. B. Caverna Passoca Cave, PETAR. C. Vereda da Palha Cave. D. Presidente Olegário karst area. E. Surrounding area of Rio dos Pombos Cave, Povoado de Igatu. F. Rio dos Pombos Cave. 


\section{Chapada Diamantina region, state of Bahia, northeastern Brazil}

Chapada Diamantina is a highland area in the central part of the state of Bahia, where several rivers have their origins. Its landscapes have great scenic beauty (e.g., mountains, waterfalls and natural pools) surrounded by the exuberant vegetation of the Caatinga domain, i.e., shrubby and thorny components typical of drier climate areas (Fig. 1E-F) (Ab'Saber 1977). According to Köppen's criteria (Alvares et al. 2013), the climate of the region is semi-arid tropical (Aw). Geologically, karst landforms predominate, with three structurally different geomorphological regions: carbonate rocks from the Una Group, intercalated with other rock types, including the Irecê Formation, which is bordered by the metamorphic sandstones of Serra do Espinhaço (Karmann \& Sánchez 1979). Altitudes vary from 1000 to $1700 \mathrm{~m}$ a.s.l., representing a natural drainage between the São Francisco and East Basins (Trajano et al. 2016). The region is considered a hotspot of cave biodiversity in Brazil. The Chapada Diamantina is protected by law (Parque Nacional Chapada Diamantina), due to its ecological relevance and scenic beauty (Trajano et al. 2016). Among the areas not yet protected, the impacts in the subterranean environments are innumerous, like the lowering of the water table, uncontrolled tourism, deforestation for agrobusiness and illegal 'garimpo' (= diamond-digging) (Gallão \& Bichuette 2018).

\section{Serra do Ramalho karst area, state of Bahia, northeastern Brazil}

The Serra do Ramalho karst area comprises several municipalities in the southwest of the state of Bahia to Minas Gerais, along the middle São Francisco river basin (Trajano et al. 2016). The Caatinga with transitions to Cerrado domains are the typical surrounding vegetation (Ab'Saber 1977). According to Koppen's criteria (Alvares et al. 2013), the climate of the region is tropical (Aw) with hot summers and a prolonged dry season in winters, from March to October. Despite the fact that the Serra do Ramalho karst area is one of the richest spots of subterranean biodiversity (Trajano et al. 2016), there is no legal protection of its caves. Deforestation for charcoal production, timber extraction and agriculture are common and, in the near future, mining will be a concrete threat (Gallão \& Bichuette 2018).

Specimens were collected inside Gruna do Enfurnado Cave, located in the municipality of Coribe. This cave was developed in Neoproterozoic metalimestones from the Bambuí Group intercalated with siltyclay and arenitic metasediments (Karmann \& Sánchez 1979). The cave itself is $7560 \mathrm{~m}$ long, crossed by two streams that connect to each other during heavy rains. Floods bring abundant and varied organic matter, sustaining a rich community inside the cave (Trajano et al. 2009).

\section{State of Sergipe, northeastern Brazil}

Sergipe is the smallest Brazilian state, comprising 75 municipalities. Among them, 18 have natural cavities (Costa et al. 2015). According to Köppen's criteria (Alvares et al. 2013), the main climate of the region is tropical with winter rainfall and dry summers (As). The vegetation is Tropical Atlantic domain, which originally covered most of the state (Ab'Saber 1977). Actually, a vast area has been deforested for pastures, even near some caves sampled in this study (Costa et al. 2015). Transition zones towards vegetation typical of drier climates appear in the northwest with small spots of Caatinga domain (Ab'Saber 1977).

Our assessment was conducted in the center of the state along a karst strip from northeast to southeast. Knowledge of the karst environments of the state of Sergipe is still incipient, but it is already known that its limestone and dolomites are from the Sergipe Group, Cotinguiba and Riachuelo Formations (Barreto et al. 2005). In this karst area, composed of limestone outcrops, caves are frequent. Because of paleoclimate conditions, only few caves have a large horizontal development, such as the Toca da Raposa $(90 \mathrm{~m})$ and Aventureiros caves $(140 \mathrm{~m})$. The caves of the Sergipe Group are warmer and wetter than usual, and food input is relatively abundant, consisting primarily of guano from frugivorous, insectivorous or hematophagous bats. Most of the environments outside the caves are well preserved, except for those near Toca da Raposa Cave, which have been suffering from deforestation (Costa et al. 2015). 
To date, no study evaluating the conservation status and threats hanging over the subterranean fauna and environments of Sergipe has been conducted. However, mining of limestone for cement and gravels used in the construction industry is intense near Laranjeiras and Nossa Senhora do Socorro (Macedo et al. 2012).

Serra dos Carajás (Canaã dos Carajás and Parauapebas), state of Pará, northern Brazil This region is part of the Equatorial Amazonian Domain, with small mountain ranges covered with Amazon forests (Ab'Saber 1977). At Serra dos Carajás, series of discontinuous mountains and hills have extensive and ancient erosions, which prevented the development of forest, contrasting with the surrounding dense forest (Campos \& Castilho 2012; Crescencio \& Carmo 2013; Campos-Filho et al. 2014). According to Köppen's criteria (Alvares et al. 2013), the climate of the region is tropical monsoon $(\mathrm{Am})$ with an annual mean temperature above $26^{\circ} \mathrm{C}$. The total annual rainfall ranges from 2200 to 2500 $\mathrm{mm}$; monsoons concentrate from February to May, with a total of ca $400 \mathrm{~mm}$ of rainfall per month during this period. Caves in this region are inserted in iron ore rocks, with connections to the surface via small spaces (Bichuette et al. 2015; Ferreira et al. 2015). Iron ore mining has been a consistent threat to the subterranean environments of Serra dos Carajás, sometimes reaching a complete destruction of landscapes and caves, by polluting soil and drainages (Gallão \& Bichuette 2018).

\section{Results}

Order Isopoda Latreille, 1817

Suborder Oniscidea Latreille, 1802

Family Philosciidae Kinahan, 1857

Genus Alboscia Schultz, 1995

\section{Type species}

Alboscia elongata Schultz, 1995, by original designation and monotypy.

Alboscia jotajota Campos-Filho, Bichuette \& Taiti sp. nov. urn:1sid:zoobank.org:act:872601F5-076C-44FD-83E7-0FC35123E54D

Figs 2-4, 14

\section{Diagnosis}

Eyes reduced to rudimentary ommatidia, distal article of antennula with six lateral aesthetascs plus apical pair and male pleopod 1 endopod slightly longer than exopod, with short and thickset distal portion.

\section{Etymology}

This new species is named after Joaquim Justino dos Santos (in memoriam), also known as 'Jota Jota', who discovered several caves in the Alto Ribeira karst area and was a fantastic guide at PETAR.

\section{Material examined}

\section{Holotype}

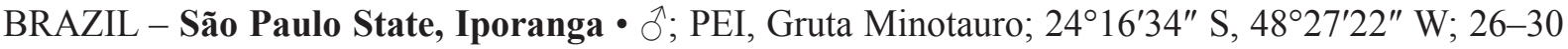
Mar. 2009, F. Pellegatti-Franco leg.; parts in micropreparations; LES 647.

\section{Paratypes}

BRAZIL - São Paulo State, Iporanga • 2 q ; PETAR, Ressurgência das Areias de Água Quente Cave; 243'ㄴ'4" S, 4840'18" W; 29 Sep. 2012; M.E. Bichuette leg.; LES 18852. 


\section{Description}

MeAsurements. Maximum body length: male $4 \mathrm{~mm}$, female $4.5 \mathrm{~mm}$.

Body. Body pigments absent. Body (Fig. 2A) slender with lateral sides almost parallel; dorsal surface smooth, bearing short, triangular scale-setae (Fig. 2B). Noduli laterales very long (Fig. 2C); d/c and b/c coordinates as in Fig. 2D-E.

CepHaLon. Lateral lobes not developed, frontal line absent, suprantennal line slightly bent downwards in middle; eyes reduced, with rudimentary ommatidia (Fig. 2F).

Pereon. Pereonite 1 epimera with anterior corners slightly directed upwards, not surpassing median portion of cephalon, epimera 2-7 gradually directed backwards (Fig. 2A).

PLEON. Narrower than pereon; pleonites 3-5 epimera short, adpressed with small posterior points directed backwards, bearing some glandular pores; telson triangular with lateral margins straight, rounded apex (Fig. 2G).

Antennula. Composed of three articles, distal article bearing six lateral aesthetases in three sets plus apical pair (Fig. 2H).

ANTENNA. Very long, reaching fourth pereonite when extended backwards; flagellum of three articles, distal article longest; apical organ short, bearing two long free sensilla (Fig. 2I).

Mouth. Mandibles bearing dense cushion of setae on incisor process, molar penicil consisting of several branches; right mandible (Fig. 3A) with $1+1$ penicils, left mandible (Fig. 3B) with $2+1$ penicils. Maxillula (Fig. 3C) inner endite with distal margin rounded and bearing two penicils; outer endite with four simple teeth plus accessory tooth on outer set, inner set of five pectinate teeth plus one vestigial tooth on rostral surface. Maxilla (Fig. 3D) inner lobe rounded, covered with thick and thin setae; outer lobe slightly wider than inner lobe, covered with thin setae. Maxilliped (Fig. 3E) palp with two strong setae on proximal article; endite subrectangular, medial seta strong, surpassing distal margin, distal margin with two hook-like setae, rostral surface with setose sulcus ending in one strong, triangular seta.

Pereopods. Pereopods 1-7 merus to propodus bearing sparse, long setae on sternal margin; pereopod 1 carpus with transverse antennal grooming brush; dactylus of two claws, inner claw not surpassing outer claw, dactylar and ungual setae simple, not surpassing outer claw.

UROPOD. Protopod subquadrangular with endopod and exopod inserted at same level; protopod and exopod outer margins grooved, bearing glandular pores; exopod slightly longer than endopod (Fig. 4A).

PleOPOD EXOPODs. Without respiratory structures (Fig. 4E-I).

\section{Male}

Pereopods 1 And 7. Without any sexual dimorphism (Fig. 4B-C).

GeNITAL PAPILLA. Stout, with triangular ventral shield, papilla slightly longer than ventral shield, bearing two apical orifices (Fig. 4D).

Pleopods. Pleopod 1 (Fig. 4E) exopod subcircular, wider than long; endopod short and stout, with distal portion thickset and slightly bent outwards, rounded apex. Pleopod 2 (Fig. 4F) exopod triangular, outer margin almost straight, bearing one seta, distal margin rounded; endopod longer than exopod. Exopods of pleopod 3 and 4 subrectangular, outer margin almost straight and bearing three long setae (Fig. 4G- 


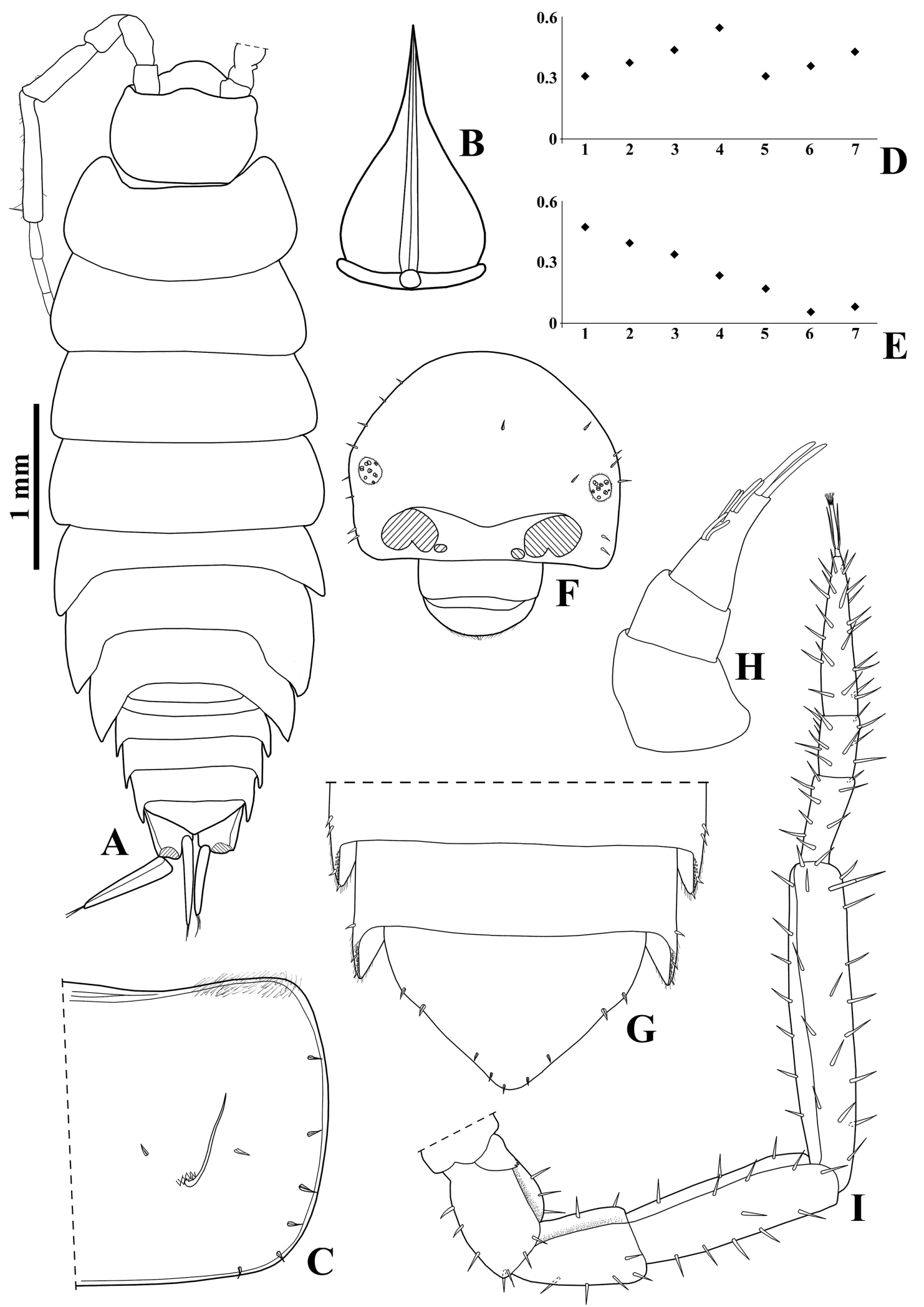

Fig. 2. Alboscia jotajota Campos-Filho, Bichuette \& Taiti sp. nov., $\uparrow$, paratype (LES 18852). A. Habitus, dorsal view. B. Dorsal scale-seta. C. Pereonite 1 epimeron, dorsal view. D. Noduli laterales d/c coordinates. E. Noduli laterales b/c coordinates. F. Cephalon, frontal view. G. Pleonites $4-5$ and telson. H. Antennula. I. Antenna. 
H). Pleopod 5 exopod (Fig. 4I) triangular, outer margin convex, bearing three long setae, distal margin rounded.

\section{Remarks}

To date, the genus Alboscia comprises four species: A. elongata Schultz, 1995 from Paraguay; A. itaipuensis Araujo \& Quadros, 2005, A. ornata Araujo, 1999 and A. silveirensis Araujo, 1999 from Brazil (Schultz 1995; Araujo 1999; Araujo \& Quadros 2005). The genus is mainly defined by the slender habitus with lateral sides almost parallel, presence of conspicuous noduli laterales, epimera of pleonites closely appressed to pleon, maxillula outer endite with pectinate teeth on outer set and pleopod exopods without respiratory structures (Araujo 1999). The presence of pectinate teeth on the outer endite of the maxillula is present in other lineages of Oniscidea, e.g., Ligia Fabricius, 1798 (Ligiidae Leach, 1814), Armadilloniscus Uljanin, 1875 (Detonidae Budde-Lund, 1906)), Benthana Budde-Lund, 1904, Benthanops Barnard, 1932 and Ctenoscia Verhoeff, 1928 (Philosciidae), and Rhyscotidae Budde-Lund,
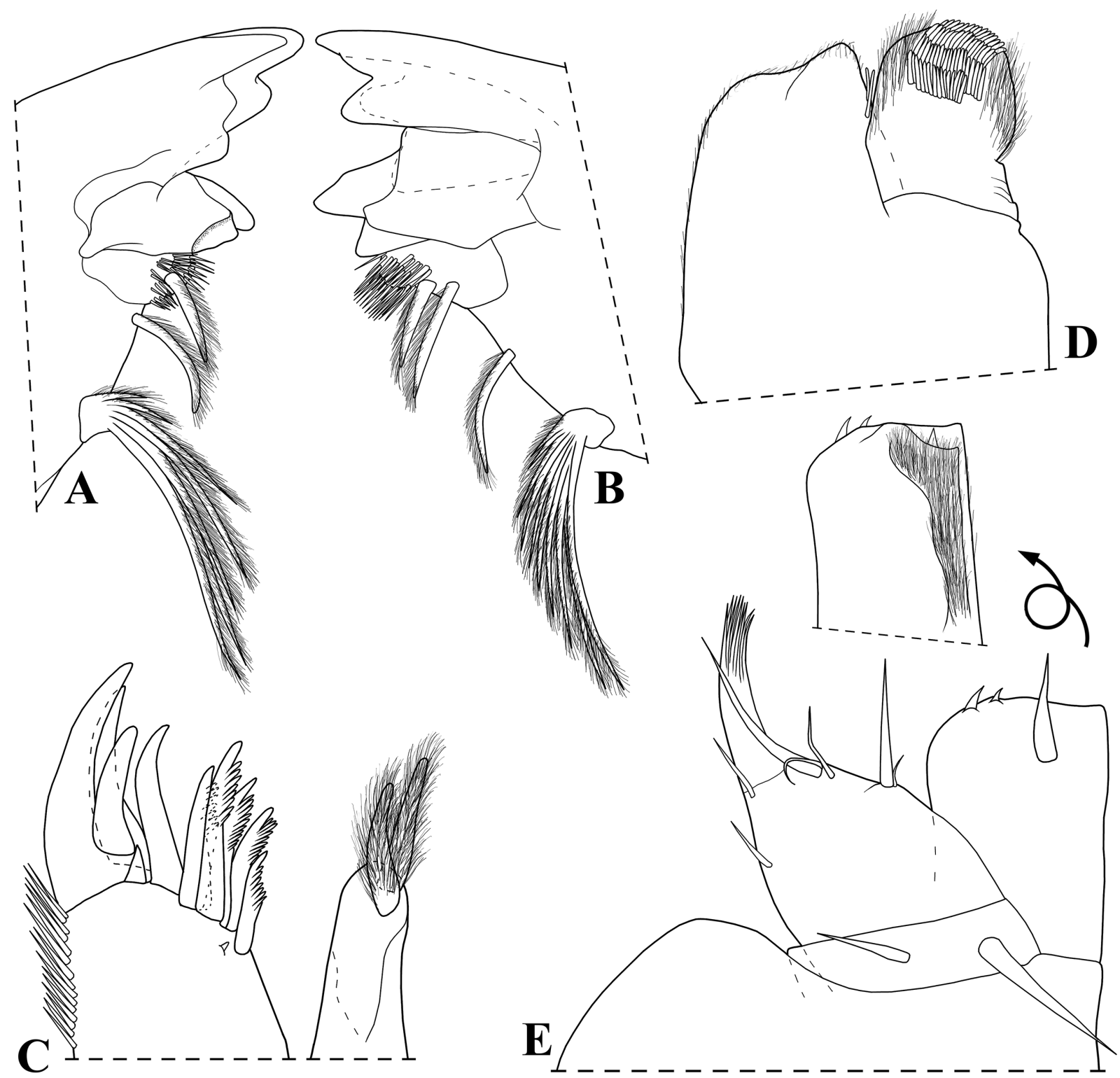

Fig. 3. Alboscia jotajota Campos-Filho, Bichuette \& Taiti sp. nov.,, , paratype (LES 18852). A. Right mandible. B. Left mandible. C. Maxillula. D. Maxilla. E. Maxilliped. 
1908 (see Taiti \& Ferrara 1982; Leistikow 1997; Schmidt 2002, 2003; Campos-Filho et al. 2015a). This character state is considered to be plesiomorphic (Leistikow 2001; Schmidt 2002).

In the shape of the male pleopod 1 exopod, Alboscia jotajota sp. nov. resembles A. elongata and A. silveirensis. It differs from both species in having eyes with rudimentary ommatidia (vs three ommatidia in A. elongata; single ommatidium in A. silveirensis), antennula with six lateral aesthetascs

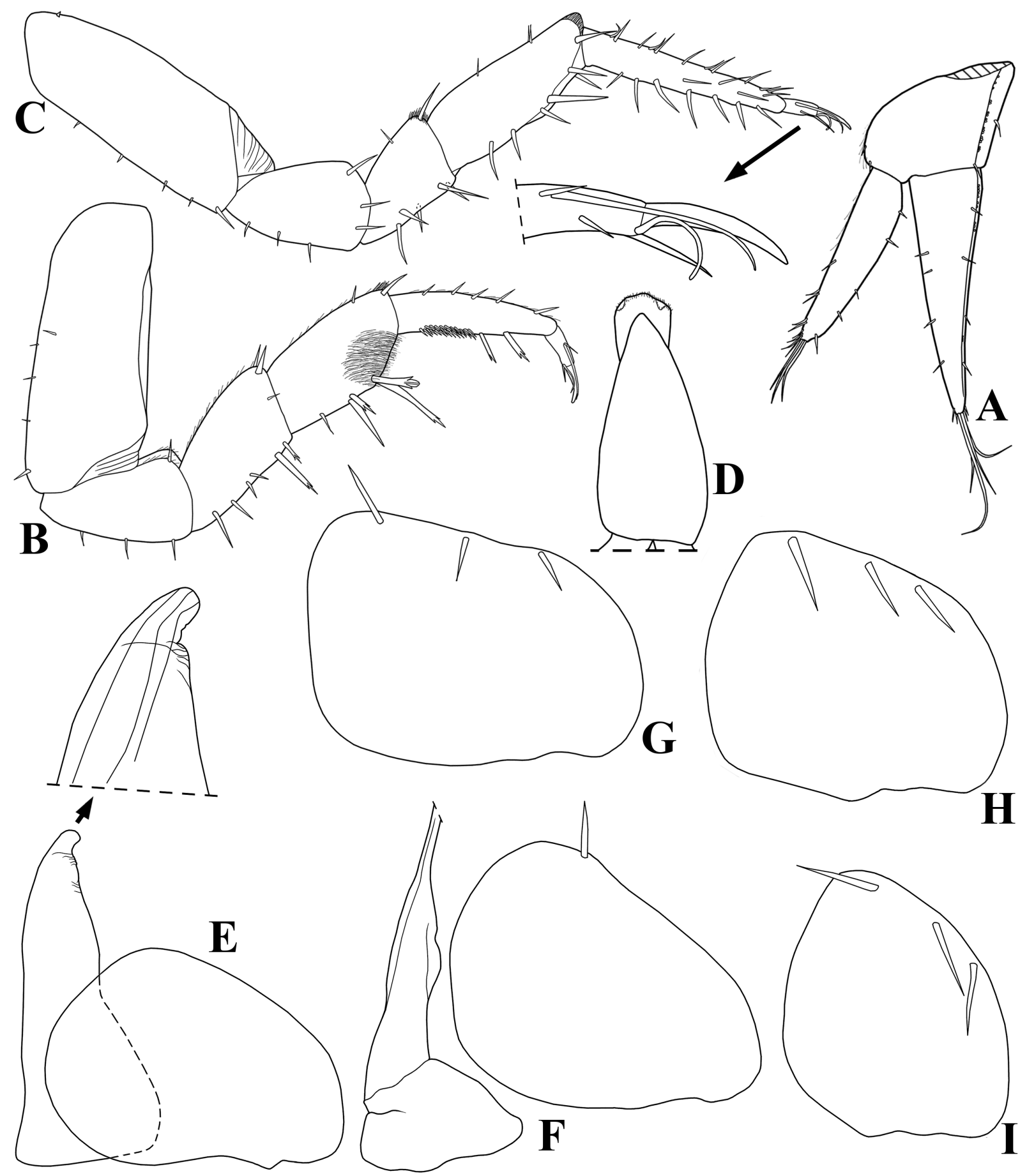

Fig. 4. Alboscia jotajota Campos-Filho, Bichuette \& Taiti sp. nov., o, paratype (LES 18852) (A) and $\widehat{\partial}$, holotype (LES 647) (B-I). A. Uropod. B. Pereopod 1. C. Pereopod 7. D. Genital papila. E. Pleopod 1. F. Pleopod 2. G. Pleopod 3 exopod. H. Pleopod 4 exopod. I. Pleopod 5 exopod. 
arranged in three sets (vs five in one set in A. elongata; two in one set in A. silveirensis) and the male pleopod 1 endopod slightly longer than the exopod, with short and thickset distal portion (vs more than twice as long as exopod and distal portion slender in A. elongata; three times as long as exopod and distal portion slender in A. silveirensis).

The absence of body pigment and absent/reduced eyes are common to all species of Alboscia, which probably indicates an endogean way of life. However, Alboscia jotajota sp. nov. is considered to be troglobiotic since no specimen was collected during surveys outside the caves where this species occurs.

Genus Androdeloscia Leistikow, 1999

\section{Type species}

Chaetophiloscia hamigera Vandel, 1952, by original designation.

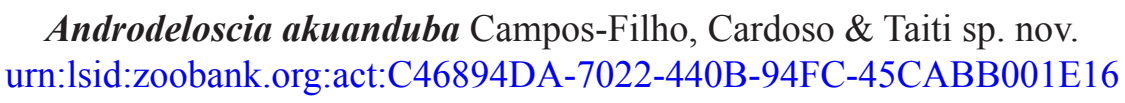

Figs $5-7,14$

\section{Diagnosis}

Eyes with eight ommatidia, telson with lateral sides almost straight, male pleopod 1 exopod heartshaped with outer margin slightly concave, and male pleopod 1 endopod with distal portion tapering, slightly bent outwards and bearing setae on medial margin.

\section{Etymology}

This new species is named after the divinity Akuanduba of the Araras native people, who is responsible to bring order to the world.

\section{Material examined}

\section{Holotype}

BRAZIL - Pará State, Serra Sul • đ̊; Floresta Nacional Carajás, Gruta N4WC15 Cave; $6^{\circ} 03^{\prime}$ S, 50¹0’ W; 20 Apr.-4 May 2010; R. Andrade leg.; MZUSP 39670.

\section{Paratypes}

BRAZIL - Pará State, Parauapebas • 6 우, 2 juvs; Gruta N4E77 Cave; $6^{\circ} 01^{\prime} 57^{\prime \prime}$ S, 50 $00^{\circ} 02^{\prime \prime}$ W; 13-30 Jan. 2010; R. Andrade leg.; MZUSP 39671 • 1 q; Gruta N4E78 Cave; 601'57" S, 5009'04" W; 19 Nov.-4 Dec. 2010; MZUSP 39672 • 1 9; Gruta S11D-79 Cave; 6²3'32" S, 50¹8'57" W; 1-14 Jul. 2010; leg. R. Andrade leg.; MZUSP 39673 • 1 o; Gruta S11D-33 Cave; 6²4'39" S, 50²0'37" W; 13-30 Jan. 2010; R. Andrade leg.; MZUSP 39674 • 1 q; Gruta S11D-37 Cave; 6²4'46" S, 50²1'30" W; 3-19 Aug. 2010; R. Andrade leg.; MZUSP 39675 - Pará State, Canaã dos Carajás • 1 q; Gruta S1123 Cave; 6²5'21" S, 50¹7'57" W; 24 Feb.-4 Mar. 2010; R. Andrade leg.; MZUSP 39676.

\section{Description}

MeAsurements. Maximum body length: male $2 \mathrm{~mm}$, female $4 \mathrm{~mm}$.

BoDy. Body with faintly visible light brown pigments. Body outline as in Fig. 5A; dorsal surface covered with triangular scale-setae (Fig. 5B). Noduli laterales very long (Fig. 5C); d/c and b/c coordinates as in Fig. 5D-E. 
Cephalon. Lateral lobes not developed; frontal line absent; suprantennal line bent downwards in middle; eyes composed of eight ommatidia (Fig. 5A, F).

Pereon. Pereonite 1 epimera with anterior corners directed frontwards; pereonites $2-4$ with posterior margins straight, 5-7 gradually arched (Fig. 5A).

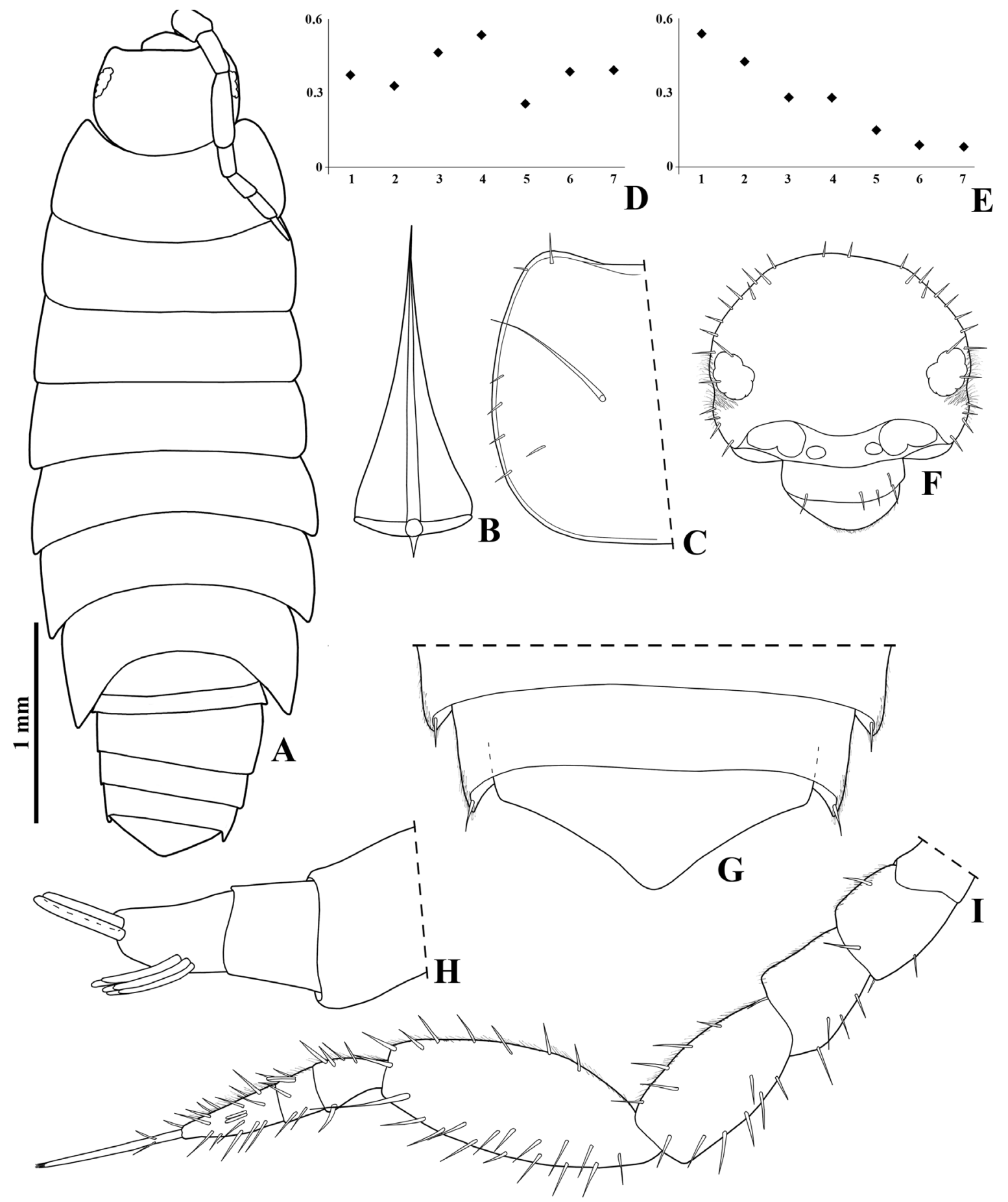

Fig. 5. Androdeloscia akuanduba Campos-Filho, Cardoso \& Taiti sp. nov., ๆ, paratype (MZUSP 39671). A. Habitus, dorsal view. B. Dorsal scale-seta. C. Pereonite 1 epimeron, dorsal view. D. Noduli laterales d/c coordinates. E. Noduli laterales b/c coordinates. F. Cephalon, frontal view. G. Pleonites $4-5$ and telson. H. Antennula. I. Antenna. 
Pleon. Narrower than pereon; epimera of pleonites 3-5 short, adpressed, with small posterior points directed backwards; telson triangular, with lateral margins slightly concave (Fig. 5A, G).

Antennula. Composed of three articles, proximal article longest, distal article bearing lateral tuft of six aesthetascs plus apical pair (Fig. 5H).

ANTENNA. Reaching pereonite 3 when extended backwards; flagellum of three articles, distal article longest and bearing two lateral aesthetascs; apical organ longer than distal article of flagellum, bearing two short, free sensilla (Fig. 5I).

Mouth. Mandibles with dense cushion of setae on incisor process, molar process of 4-6 branches, right mandible (Fig. 6A) with $1+1$ penicils, left mandible (Fig. 6B) with $2+1$ penicils. Maxillula (Fig. 6C)

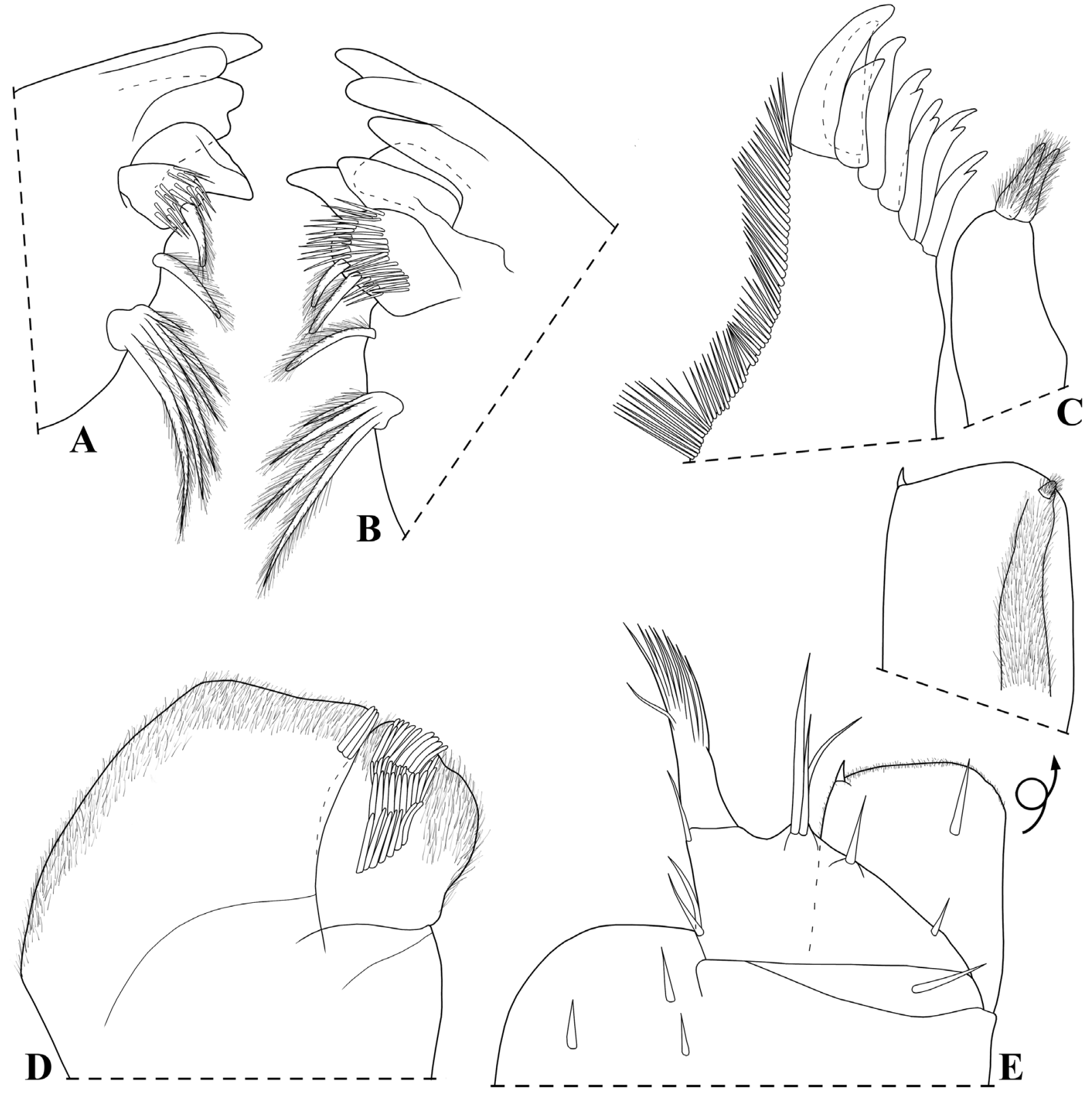

Fig. 6. Androdeloscia akuanduba Campos-Filho, Cardoso \& Taiti sp. nov., +, paratype (MZUSP 39671).

A. Right mandible. B. Left mandible. C. Maxillula. D. Maxilla. E. Maxilliped. 
inner endite with two apical penicils; outer endite with $4+4$ teeth, inner set apically cleft, outer margin strongly concave. Maxilla (Fig. 6D) inner lobe rounded, covered with thick and thin setae; outer lobe twice as wide as inner lobe, covered with thin setae, distal margin truncate. Maxilliped (Fig. 6E) palp

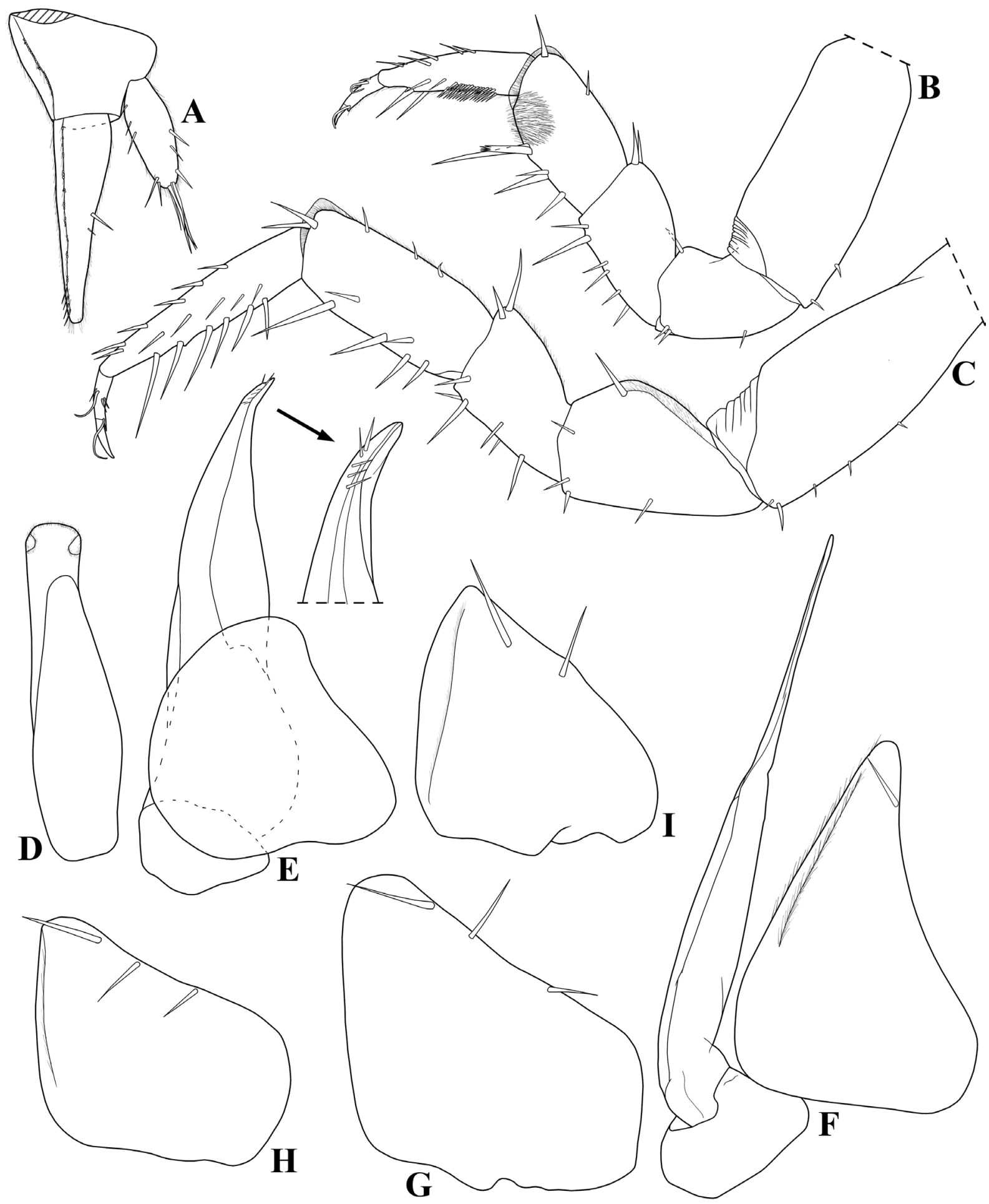

Fig. 7. Androdeloscia akuanduba Campos-Filho, Cardoso \& Taiti sp. nov.,, , paratype (MZUSP 39671) (A) and $\widehat{\text { O}}$, holotype (MZUSP 39670) (B-I). A. Uropod. B. Pereopod 1. C. Pereopod 7. D. Genital papilla. E. Pleopod 1. F. Pleopod 2. G. Pleopod 3 exopod. H. Pleopod 4 exopod. I. Pleopod 5 exopod. 
with one seta on proximal article; endite subrectangular, medial seta slightly surpassing distal margin, distal margin bearing one seta on outer portion, rostral surface with setose sulcus ending in one penicil.

Pereopods. Pereopod 1-7 merus to propodus bearing sparse setae on sternal margin, pereopod 1 (Fig. 7B) carpus with short transverse antennal grooming brush; dactylus of two claws, inner claw short, dactylar seta simple, not surpassing outer claw, ungual seta simple, surpassing outer claw.

UROPOD. Protopod subquadrangular; protopod and exopod outer margins grooved, bearing glandular pores; exopod twice as long as endopod, endopod inserted proximally (Fig. 7A).

PLEOPOD EXOPODS. Without respiratory structures.

\section{Male}

Pereopods 1 AND 7. Without sexual dimorphism (Fig. 7B-C).

Genital papilla. Bearing triangular ventral shield, papilla longer than ventral shield bearing two subapical orifices (Fig. 7D).

Pleopods. Pleopod 1 (Fig. 7E) exopod heart-shaped, outer margin slightly concave; endopod twice as long as exopod, distal portion tapering, slightly bent outwards and bearing setae on medial margin. Pleopod 2 (Fig. 7F) exopod triangular, outer margin concave bearing one seta; endopod flagelliform, distinctly longer than exopod. Exopods of pleopod 3 and 4 (Fig. 7G-H) rhomboid, outer margin slightly concave and bearing three long setae. Pleopod 5 exopod (Fig. 7I) triangular, outer margin almost straight, bearing two long setae, inner margin grooved to accommodate pleopod 2 endopod.

\section{Remarks}

The genus Androdeloscia comprises 25 species distributed in the tropical forest areas of South and Central America (Schmalfuss 2003; Schmidt \& Leistikow 2005; Grangeiro \& Souza 2006; Grangeiro \& Christoffersen 2010; López-Orozco et al. 2016). The genus is mainly defined by animals with reduced length, antennula with one lateral tuft of aesthetascs plus an apical pair, antennal flagellum of three articles and long apical organ, $\mathrm{d} / \mathrm{c}$ noduli laterales coordinates with nodulus 4 distant from the lateral margin, male pleopod 1 exopod rounded, endopod stout, bearing a complex distal apparatus, male pleopod 2 endopod elongated and male pleopod 5 exopod grooved on inner margin and distally elongated to accommodate the endopod of pleopod 2 (see Leistikow 1999; Schmidt \& Leistikow 2005). Most of these characters are present in Androdeloscia akuanduba sp. nov., although the male pleopod 1 exopod is heartshaped, the endopod lacks a distal complex apparatus and the male pleopod 5 exopod does not have the distal portion elongated. However, these characteristics are also observed in other species of the genus: A. digitata Leistikow, 1999, A. merolobata Leitiskow, 1999, A. muscorum Schmidt \& Leistikow, 2005, A. longiunguis Leistikow, 1999 and A. silvatica (Lemos de Castro \& Souza, 1986) have the male pleopod 1 exopod that is heart-shaped (see Leistikow 1999; Schmidt \& Leistikow 2005); A. pseudosilvatica Leistikow, 1999 has the male pleopod 1 endopod without a distal complex apparatus (Leistikow 1999); and A. colombiana López-Orozco, Carpio-Diaz \& Campos-Filho, 2016, A. dalensi Leistikow, 1999, A. opercularis Leistikow, 1999, A. pseudosilvatica, and A. silvatica do not have the distal portion of the male pleopod 5 exopod elongated (Leistikow 1999; López-Orozco et al. 2016). This species is probably troglophilic. Future surveys in- and outside caves are necessary to confirm this statement.

Genus Atlantoscia Ferrara \& Taiti, 1981

\section{Type species}

Atlantoscia alceui Ferrara \& Taiti, 1981, by monotypy (junior synonym of Philoscia floridana Van Name, 1940). 
Atlantoscia inflata Campos-Filho \& Araujo, 2015

Fig. 14

Atlantoscia inflata Campos Filho \& Araujo in Zimmermann et al., 2015a: 705, figs 1-2, 5-6, tables 1-3.

Atlantoscia inflata - Zimmermann et al. 2018a: 475, figs 5-6, tables 1-2. — Zimmermann et al. 2018b: figs $1-4$.

\section{Material examined}

BRAZIL - São Paulo State, Iporanga, PETAR • 1 đ , 1 \&; outside Caverna Morro Preto; 24³1'50" S,

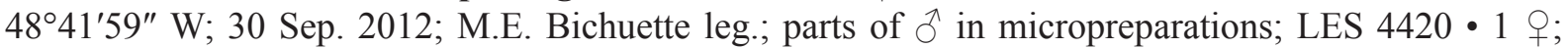
Passoca de Cima; 243'ㄱ'57" S, 4843'00" W; 3 Aug. 2013; M.E. Bichuette leg.; LES 18853.

\section{Distribution}

Typical in Atlantic forest areas in the states of Rio Grande do Sul and Paraná (Zimmermann et al. 2015a, Campos-Filho et al. 2018a). This is the first record of the genus for the subterranean environment and it extends the known distribution of this species to the state of São Paulo.

Genus Benthana Budde-Lund, 1908

\section{Type species}

Philoscia picta Brandt, 1833, by subsequent designation (Van Name 1936).

Benthana iporangensis Lima \& Serejo, 1993

Fig. 14

Benthana iporangensis Lima \& Serejo, 1993: 490, figs 1-4.

Benthana iporangensis - Pinto-da-Rocha 1995: 97. — Souza-Kury 1998: 659. — Leistikow \& Wägele 1999: 14. - Schmalfuss 2003: 53. - Campos-Filho et al. 2015a: 44. figs 30-31, 32c. — Pires et al. 2015: 69, table 1. - Trajano et al. 2016: 1819. — Bastos-Pereira et al. 2017: 292. — Cavalcanti 2017: 49, table 2. — Gallão \& Bichuette 2018: 7, table 1. — Campos-Filho et al. 2018a: 10. — Fernandes et al. 2019: 1106, table 1.

\section{Material examined}

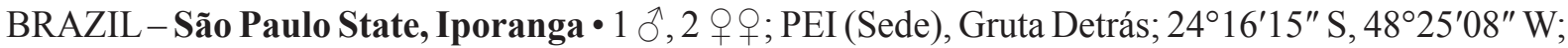

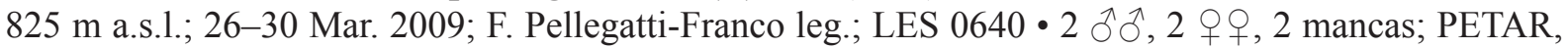

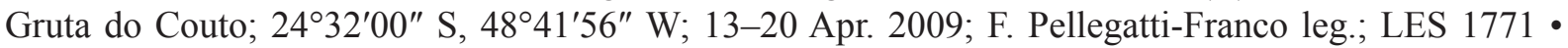

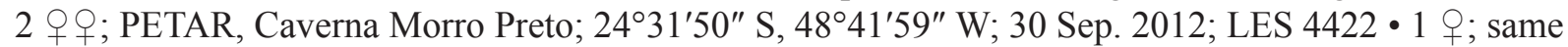
collection data as for preceding; LES $4425 \bullet 5$ q $O$; same collection data as for preceding; LES 4426.

\section{Distribution}

Benthana iporangensis was described from three caves in the Areias system: Ressurgência das Areias de Água Quente, Areias de Cima and Areias de Baixo caves, Alto Ribeira karst area, state of São Paulo (Lima \& Serejo 1993). Our records extend the known distribution of this species to other caves within the Alto Ribeira karst area. This species is recorded only from caves and is considered to be troglobiotic.

\section{Benthana longicornis Verhoeff, 1941}

\section{Fig. 14}

Benthana longicornis Verhoeff, 1941: 121, figs 1-7. 
Benthana longicornis - Gruner 1955: 446, figs 10-13. - Lemos de Castro 1958: 115, figs 93-98. Andersson 1960a: 557, fig. 10; 1960b: 415. - Araujo et al. 1996: 115, figs 5-10. - Souza-Kury 1998: 659. - Leistikow \& Wägele 1999: 14. — Schmalfuss 2003: 53. — Costa et al. 2014: 173, fig. 3. - Campos-Filho et al. 2015a: 13, figs 5-6, 9c; 2018a: 10.

\section{Material examined}

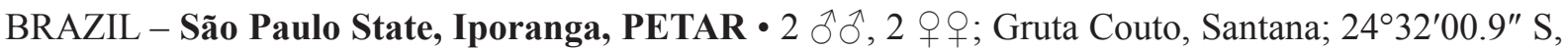
48 41'56" W; 16-20 Sep. 2009; F. Pellegatti-Franco leg.; LES 1783 • 1 § , 3 우 우 Gruta Chapéu Mirim

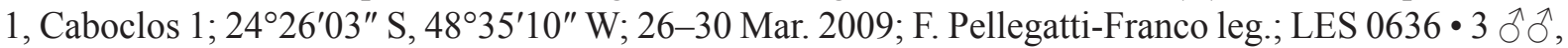
3 우; Gruta do Capinzal, Bulhas D’água; $24^{\circ} 19^{\prime} 05^{\prime \prime}$ S, 48 $30^{\prime} 05^{\prime \prime}$ W; 16 Feb. 2013; M.E. Bichuette, J.E. Gallão and T. Zepon leg.; LES 18854 • 1 क; same collection data as for preceding; LES 18855.

\section{Distribution}

Typical in Atlantic forest areas in the states of Rio de Janeiro (= Distrito Federal in Campos-Filho et al . 2015a), São Paulo, Paraná and Santa Catarina (Campos-Filho et al. 2018a). This is the first record of this species in cave environments, suggesting a troglophilic status.

\section{Benthana olfersii (Brandt, 1833)}

Fig. 14

Philoscia Olfersii Brandt, 1833: 183.

Benthana olfersii - Campos-Filho et al. 2018a: 11 (for previous records).

\section{Material examined}

BRAZIL - Minas Gerais State, Itabirito • 1 ' ; Caverna VL-33; 20¹9’54" S, 4356'15" W; 29 Mar.3 Apr. 2012; Andrade leg.; LES 18860.

\section{Distribution}

Typical in Atlantic forest areas in the states of Rio de Janeiro and São Paulo (Campos-Filho et al. 2015a). This is the first record of this species in cave environments, suggesting a troglophilic status.

\section{Benthana picta (Brandt, 1833)}

Fig. 14

Philoscia picta Brandt, 1833: 183.

Benthana picta - Campos-Filho et al. 2018a: 11 (for previous records). - Fernandes et al. 2019: 1106, table 1.

\section{Material examined}

BRAZIL - São Paulo State, Alto Ribeira karst area • 2 q + ; PEI, Gruta Beija-flor; 24¹6'25.6" S, 48 25'11.1" W; 26-30 Mar. 2009; F. Pellegatti-Franco leg.; LES 0634 • 1 ふै; PEI, Gruta Colorida;

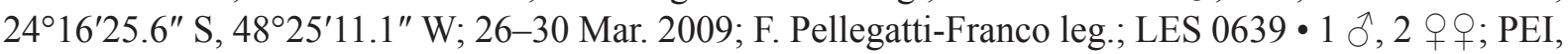
Gruta Meninos; $24^{\circ} 15^{\prime} 58^{\prime \prime}$ S, 48²4'57" W; 26-30 Mar. 2009; F. Pellegatti-Franco leg.; LES 0637 • 1 đ; PEI, Gruta Detrás; $24^{\circ} 16^{\prime} 14.5^{\prime \prime}$ S, 48 $25^{\prime} 0.9^{\prime \prime}$ W; 14-16 Sep. 2009; F. Pellegatti-Franco leg.; LES 1782 • 1 9; PETAR, Gruta Santana; $24^{\circ} 32^{\prime} 0.9^{\prime \prime}$ S, 48 $41^{\prime} 58^{\prime \prime}$ W; $14-16$ Sep. 2009; F. Pellegatti-Franco

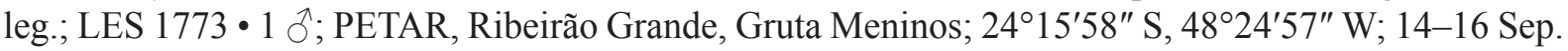
2009; F. Pellegatti-Franco leg.; LES 1787 • $1{ }^{\top}$; PETAR, Caverna Morro Preto; $24^{\circ} 32^{\prime} 00^{\prime \prime}$ S, $48^{\circ} 41^{\prime} 56^{\prime \prime} \mathrm{W}$; 30 Sep. 2012; LES $4422 \bullet 1$ क; same collection data as for preceding; LES $4423 \bullet 1$; ; PETAR, Gruta Tatu; 24¹6'16.8" S, 48²5'2.7" W; 26-30 Mar. 2009; F. Peleggatti-Franco leg.; LES 0633 • 1 ○; 


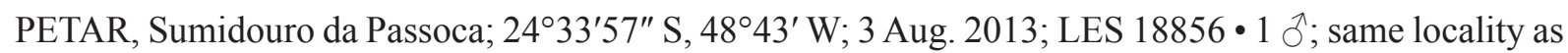
preceding; 3 Aug. 2013; LES 18857 • 1 + ; PETAR, outside Gruta Santana; 2432'00.9" S, 48 41' $58^{\prime \prime}$ W;

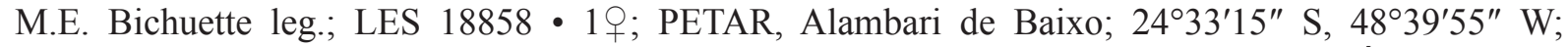
2 Oct. 2012; M.E. Bichuette leg.; LES 4367 • 1 đ’; PETAR, Ressurgência das Areias de Água Quente;

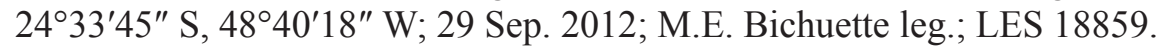

\section{Distribution}

Typical in Brazilian Atlantic forest areas from the state of Espírito Santo to Rio Grande do Sul, and in Paraguay, Villarica District, Guair Department (Campos-Filho et al. 2015a). This is the first record of this species in cave habitats. The wide occurrence and abundance inside caves suggest a troglophilic status.

Benthana taeniata Araujo \& Buckup, 1994

Fig. 14

Bentheana taeiata Araujo \& Buckup, 1994: 269, figs 1-13, 28.

Benthana taeniata - Campos-Filho et al. 2018a: 11 (for previous records).

\section{Material examined}

BRAZIL - São Paulo State, Alto Ribeira karst area, PETAR • 1 đ ; Ressurgência das Areias de Água

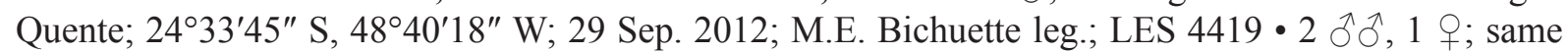
collection data as for preceding; LES $4421 \bullet 1$ क ; same collection data as for preceding; LES 18861 •

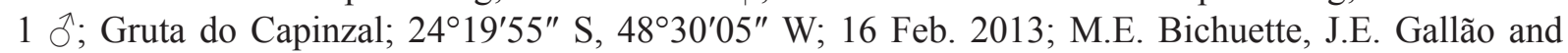
T. Zepon leg.; LES 18862.

\section{Distribution}

Benthana taeniata has been recorded from the states of Distrito Federal (capital of Brazil) to the state of Rio Grande do Sul (Campos-Filho et al. 2015a). In cave habitats, this species was recorded from Gruta Zeferino I, São Roque de Minas and Serra da Canastra, Minas Gerais State (Campos-Filho et al. 2014). The species is probably troglophilic.

Genus Metaprosekia Leistikow, 2000

\section{Type species}

Metaprosekia nodilinearis Leistikow, 2000, by original designation and monotypy.

Metaprosekia igatuensis Campos-Filho, Fernandes \& Bichuette sp. nov. urn:1sid:zoobank.org:act:24B7CEE5-59B7-4943-AA9A-D50D79BD995D

Figs $8-10,14$

Metaprosekia sp. - Fernandes et al. 2019: 1108, table 1.

\section{Diagnosis}

Telson with lateral sides almost straight, mandibles with molar penicil simple, maxillula outer endite of $4+5$ teeth (two apically cleft), male pleopod 1 exopod subtriangular with outer and inner margins slightly convex, male pleopod 2 endopod with distal portion slender.

\section{Etymology}

This new species is named after the locality where the specimens were collected, Povoado de Igatu, which holds a high diversity of subterranean fauna. 


\section{Material examined}

Holotype

BRAZIL - Bahia State, Andaraí - ô; Povoado de Igatu, Gruna Rio dos Pombos; 1254'12" S, 4119'04" W; 31 Feb. 2013; M.E. Bichuette, J.E. Gallão and D.M. Schimonsky leg.; LES 6349.

\section{Paratypes}

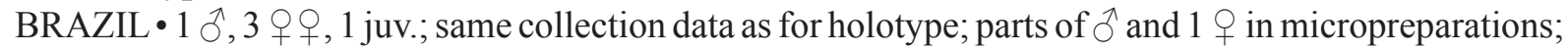
LES 6349.

\section{Description}

MEASUREMENTs. Maximum body length: male and female $2 \mathrm{~mm}$.

BoDy. Body pigment absent. Body outline as in Fig. 8A; dorsal surface densely covered with fan-shaped scale-setae (Fig. 8B). Noduli laterales piliform (Fig. 8C); d/c and b/c coordinates as in Fig. 8D-E.

Cephalon. Lateral lobes and frontal line absent; suprantennal line bent downwards in middle; eyes composed of four ommatidia (Fig. 8A, F).

Pereon. Pereonite 1 epimera with anterior corners slightly directed frontwards; pereonites 1-4 with posterior margins straight, 5-7 gradually arched (Fig. 8A).

PLEON. Slightly narrower than pereon, epimera of pleonites 3-5 short and directed backwards; telson more than twice as long as wide, triangular with lateral margins almost straight, with rounded apex (Fig. 8G).

Antennula. Composed of three articles, proximal article longest, distal article conical, bearing one lateral tuft of five aesthetascs plus apical pair (Fig. 8H).

ANTENNA. Reaching pereonite 3 when extended backwards; flagellum of three articles, medial and distal articles subequal in length; apical organ long, bearing two short free sensilla (Fig. 8I).

Mouth. Mandibles with dense cushion of setae on incisor process, molar process simple, left mandible (Fig. 9A) with $2+1$ penicils, right mandible (Fig. 9B) with $1+1$ penicils. Maxillula (Fig. 9C) inner endite with two apical penicils and small triangular point; outer endite with $4+5$ teeth, inner set with two teeth apically cleft. Maxilla (Fig. 9D) inner lobe rounded, covered with thick setae; outer lobe rounded, three times as wide as inner lobe, covered with thin setae. Maxilliped (Fig. 9E) palp with two setae on proximal article; endite subrectangular, medial seta surpassing distal margin, distal margin bearing outer tip, rostral surface with setose sulcus ending with one short penicil.

PEREOPODS. Pereopod 1-7 merus to propodus bearing sparse setae on sternal margin, pereopod 1 carpus with short transverse antennal grooming brush and distal seta hand-like; dactylus of two claws, inner claw shorter, dactylar seta simple, not surpassing outer claw, ungual seta simple, slightly surpassing outer claw.

UROPOD. Protopod subquadrangular; protopod and exopod outer margins grooved, bearing glandular pores; exopod twice as long as endopod, endopod inserted proximally (Fig. 10A).

PLEOPOD EXOPODS. Without respiratory areas.

\section{Male}

Pereopods 1 and 7. Without sexual dimorphism (Fig. 10B-C).

Genital PAPILLA. Bearing triangular ventral shield, papilla slightly longer than ventral shield, bearing two subapical orifices (Fig. 10D). 
Pleopods. Pleopod 1 (Fig. 10E) exopod subtriangular, with outer and inner margins slightly convex; endopod more than twice as long as exopod, distal portion tapering, slightly directed outwards and bearing small setae on medial margin. Pleopod 2 (Fig. 10F) exopod triangular, outer margin concave

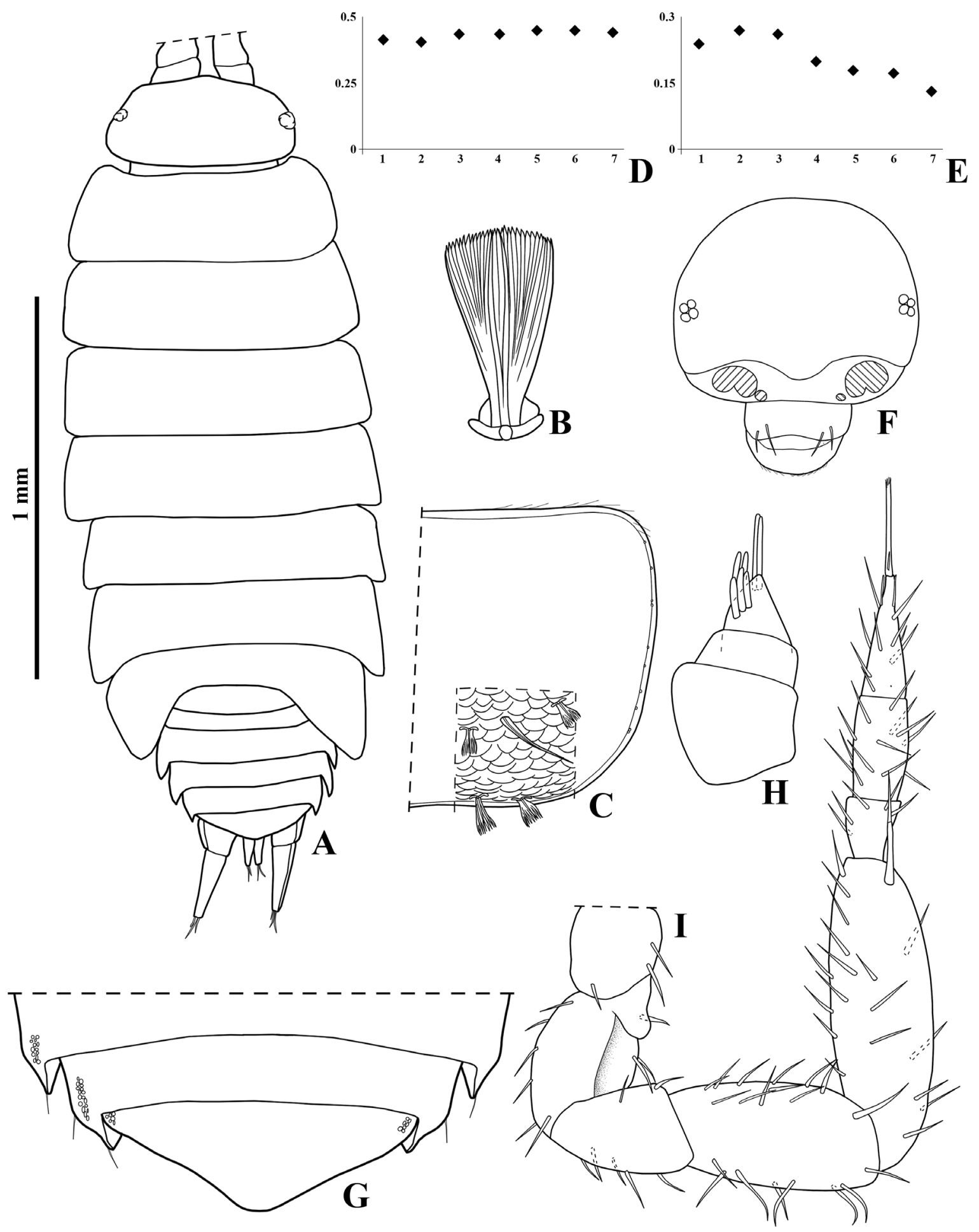

Fig. 8. Metaprosekia igatuensis Campos-Filho, Fernandes \& Bichuette sp. nov., , paratype (LES 6349). A. Habitus, dorsal view. B. Dorsal scale-seta. C. Pereonite 1 epimeron, dorsal view. D. Noduli laterales d/c coordinates. E. Noduli laterales b/c coordinates. F. Cephalon, frontal view. G. Pleonites 4-5 and telson. H. Antennula. I. Antenna. 
bearing one seta; endopod flagelliform, longer than exopod. Exopods of pleopods 3 and 4 as in Fig. 10G and H, respectively. Pleopod 5 exopod (Fig. 10I) rhomboid, outer margin convex, bearing five long setae, inner margin grooved to accommodate pleopod 2 endopod.

\section{Remarks}

The genus Metaprosekia comprises three species: M. nodilinearis Leistikow, 2000 from the department of Merida, Venezuela; M. caupe Campos-Filho, Araujo \& Taiti, 2014 and M. quadriocellata CamposFilho, Araujo \& Taiti, 2014 from the state of Pará, Brazil (Leistikow 2000; Campos-Filho et al. 2014). The genus is mainly defined by its small size, dorsal surface covered with fan-shaped or pointed scale-setae, epimera of pereonites 1-7 with noduli laterales inserted at same level from lateral margins, cephalon with suprantennal line and eyes of 3-4 ommatidia, antennula with one lateral tuft of aesthetascs plus apical pair, maxillula outer endite with $4+4$ teeth (some of them cleft at apex), maxilliped endite with rostral penicil and pleopod exopods without respiratory structures (see Leistikow 2000; Campos-Filho et al. 2014).

The new species differs from other species of the genus in having the mandibles with molar penicil simple instead of dichotomized, the shape of the male pleopod 1 and male pleopod 2 endopod, with the distal portion slender rather than thick. Moreover, it differs in having the suprantennal line bent downwards in the middle (vs. straight in M. caupe and M. nodilinearis; slightly bent downwards in M. quadriocellata) and in having the apical organ of the antennal flagellum shorter than the distal article (vs subequal in M. caupe; longer in M. nodilinearis and M. quadriocellata).

The presence of fan-shaped scale-setae is related with the creeper eco-morphological strategy (Schmalfuss 1984), which functionally reduces the adhesive forces and facilitates the movement of the animal in unconsolidated substrates. However, this is not the case for species of Metaprosekia.
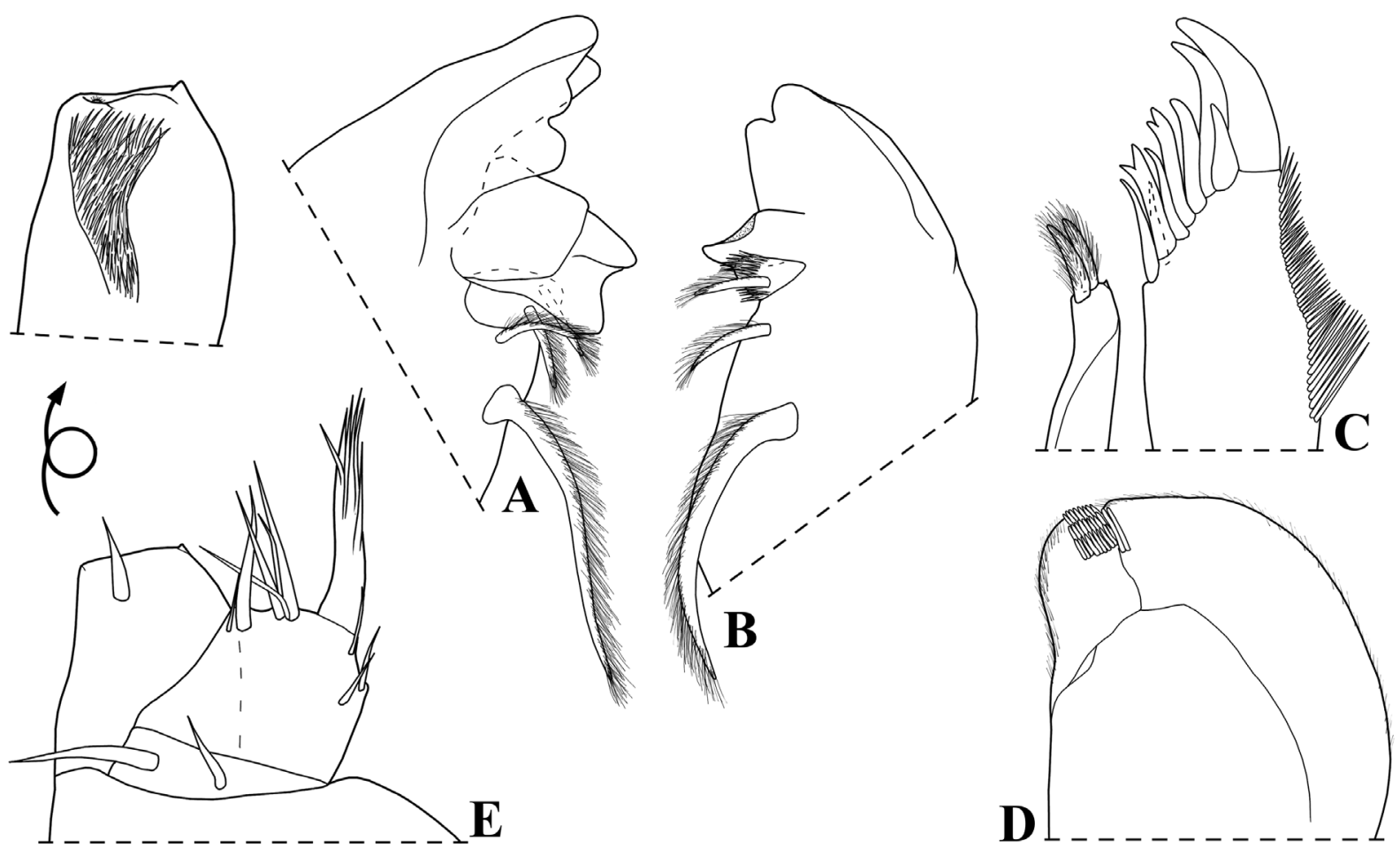

Fig. 9. Metaprosekia igatuensis Campos-Filho, Fernandes \& Bichuette sp. nov., +, paratype (LES 6349). A. Left mandible. B. Right mandible. C. Maxillula. D. Maxilla. E. Maxilliped. 
As mentioned by Campos-Filho et al. (2014), the presence of fan-shaped scale-setae on the dorsal surface and of eyes with a reduced number of ommatidia can be related to an endogean life-style. This species is considered here as troglobiotic, since many expeditions were carried out outside the cave where it was collected and no specimens were found.

Genus Paratlantoscia Zimmermann, Campos-Filho \& Araujo, 2018

\section{Type species}

Paratlantoscia robusta Zimmermann, Campos-Filho \& Araujo, 2018, by original designation.

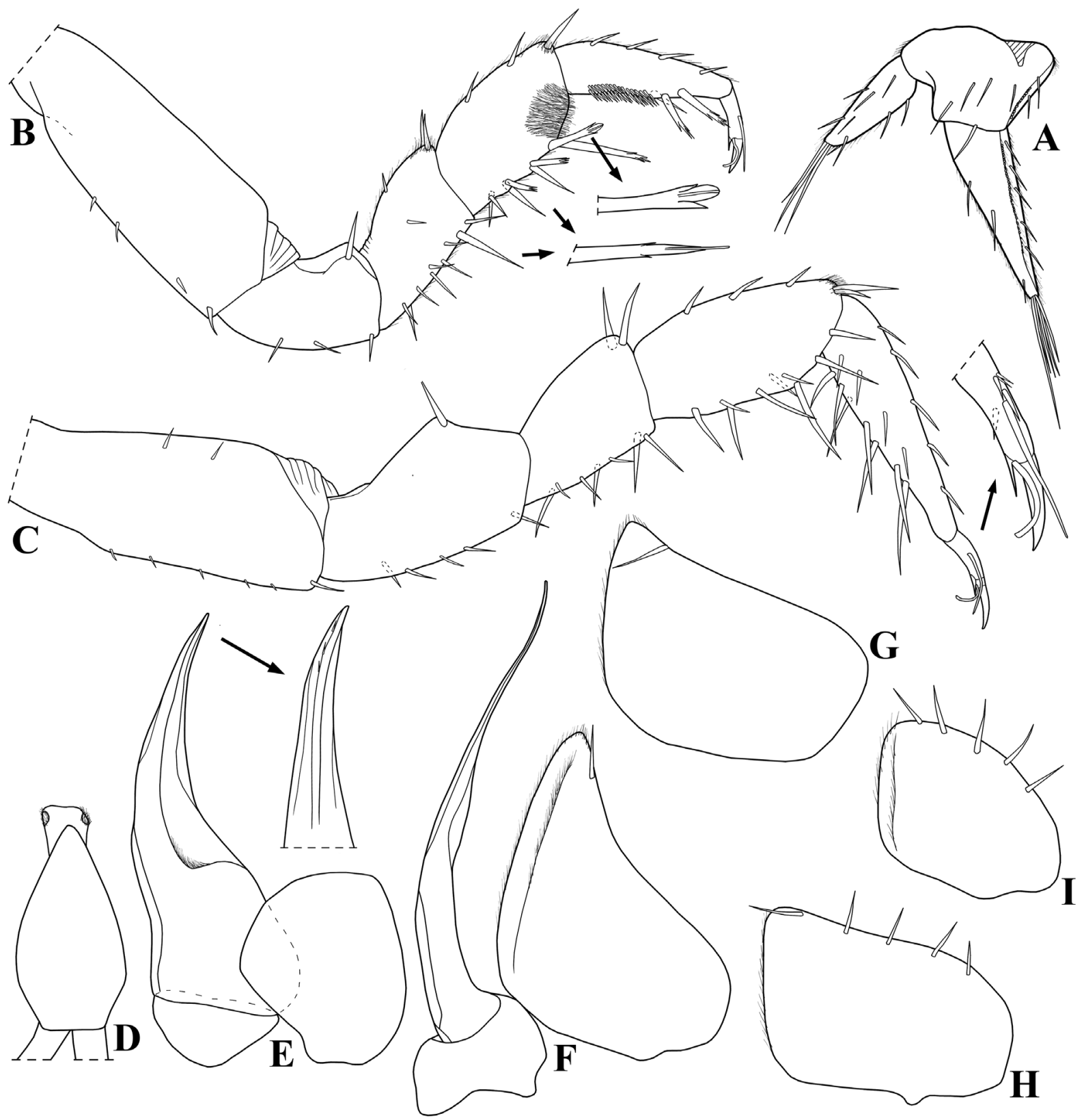

Fig. 10. Metaprosekia igatuensis Campos-Filho, Fernandes \& Bichuette sp. nov., +, paratype (LES 6349) (A) and $\widehat{\partial}$, paratype (LES 6349) (B-I). A. Uropod. B. Pereopod 1. C. Pereopod 7. D. Genital papilla. E. Pleopod 1. F. Pleopod 2. G. Pleopod 3 exopod. H. Pleopod 4 exopod. I. Pleopod 5 exopod. 
Atlantoscia rubromarginata Araujo \& Leistikow, 1999: 110, figs 1-5.

Atlantoscia rubromarginata - Leistikow 2001: 6. - Schmalfuss 2003: 49. - Campos-Filho et al. 2012: 141; 2013: 466, fig. 12b. — Lisboa et al. 2013: 394. — Zimmermann et al. 2015a: 704, figs. 5-6, tables $1-3 ; 2015$ b: 3 , table 1 .

Paratlantoscia rubromarginata - Zimmermann et al. 2018a: 474, figs 5-6, tables 1-2. — Campos-Filho et al. 2018a: 14.

\section{Material examined}

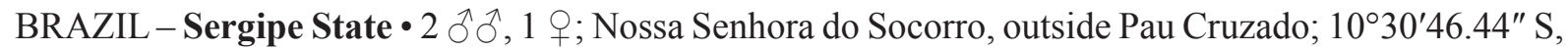
376'2.52" W; 20 Oct. 2014; M.E. Bichuette, D. Cardoso, M. Bolfarini, M. Rosendo and R. Moreira leg.; LES 10818 • 3 우우 Laranjeiras, Caverna dos Aventureiros; 1048'11.6" S, 37 10'50" W; 20 Oct. 2014; M.E. Bichuette, D. Cardoso, M. Bolfarini, M. Rosendo and R. Moreira leg.; LES 10819 • 1 §; Japaratuba, Caverna Casa do Caboclo; 10³7'57.16" S, 36 52'59.10" W; 19 Oct. 2014; M.E. Bichuette, D. Cardoso, M. Bolfarini, M. Rosendo and R. Moreira leg.; LES 10820 - 4 juvs; Murici, Fazenda São José, Caverna Toca da Raposa; 9¹3'35.95" S, 3554'46.23" W; 22 Oct. 2014; M.E. Bichuette, D. Cardoso, M. Bolfarini, M. Rosendo and R. Moreira leg.; LES 10828.

\section{Distribution}

This species has been recorded from Atlantic and Amazon forest areas in the states of Alagoas, Bahia, Pará and Sergipe (Campos-Filho et al. 2013, 2017a). This is the first record of this species in the subterranean environment, but $P$. rubromarginata is considered here as trogloxene.

Family Scleropactidae Verhoeff, 1938

Genus Amazoniscus Lemos de Castro, 1967

\section{Type species}

Amazoniscus arlei Lemos de Castro, 1967, by original designation and monotypy.

Amazoniscus spica Campos-Filho, Aguiar \& Taiti sp. nov. urn:lsid:zoobank.org:act:C67F79F2-111D-49D7-A9E2-FA112D32DB4B

Figs 11-14

\section{Diagnosis}

Body pigments and eyes absent, frontal shield bent backwards over vertex, dactylus of pereopods with ungual seta simple and surpassing outer claw, male pleopod 1 exopod heart-shaped and male pleopod 1 endopod with distal portion bent outwards, bearing small setae on median margin.

\section{Etymology}

The name of this new species refers to the binary star of Spica, the brightest star in the Virgo constellation. In the Brazilian flag, this star represents the state of Pará.

\section{Material examined}

\section{Holotype}

BRAZIL - Pará State, Parauapebas, Canaã dos Carajás • ${ }^{7}$; Jaguar, CAV-20; $6^{\circ} 24^{\prime} 22^{\prime \prime}$ S, 50 $22^{\prime} 09^{\prime \prime}$ W; 20-29 May 2012; Mescolotti leg.; MZUSP 40046. 
Paratypes

BRAZIL $-1 \hat{\partial}, 2$ q $O$; same collection data as for holotype; parts of $\hat{\partial}$ and 1 in micropreparations; MZUSP 40047 • 1 +; CAV-17; 6²4'24" S, 50²2'10" W; 8-15 Mar. 2012; Oliveira leg.; MZUSP 40048.

\section{Description}

Measurements. Maximum body length: male and female $5.5 \mathrm{~mm}$.

Body. Body pigment absent. Endoantennal conglobation. Body (Fig. 11A) strongly convex; dorsal surface smooth, bearing small triangular scale-setae (Fig. 11B). Noduli laterales (Fig. 11C) very short, inserted near posterior margins and at same distance from lateral margins.

Cephalon. Frontal shield bent backwards over vertex, lateral sides slightly protruding in frontal view, frontal margin broadly rounded; eyes absent (Fig. 11A, D-E).

Pereon. Pereonite 1 without schisma or ventral lobes; pereonites 1-4 with posterior margin straight, 5-7 gradually more concave; pereonite 1 epimera with anterior corners directed frontwards, those of 2-4 with outer margin rounded, and those of 5-7 subquadrangular (Fig. 11A).

Pleon. Outline continuous with pereon, epimera 3-5 well developed, directed backwards with acute apices; telson triangular, slightly broader than long, with slightly concave sides, rounded apex. (Fig. 11F).

ANTENNULA. Composed of three articles, distal article longest, conical bearing about 10 lateral aesthetascs arranged in five sets (Fig. 11G).

ANTENNA. Short and stout, not surpassing pereonite 1 when extended backwards; flagellum consisting of two subequal articles, distal article bearing two lateral aesthetascs; apical organ as long as distal article of flagellum (Fig. 11H).

Mouth. Mandibles with dense cushion of setae on incisor process, molar process with 10 branches, left mandible (Fig. 12A) with $2+1$ penicils, right mandible (Fig. 12B) with $1+1$ penicils. Maxillula (Fig. 12C) inner endite with two apical penicils, distal margin bearing outer tip; outer endite with $4+5$ teeth, inner set with four teeth, apically cleft. Maxilla (Fig. 12D) inner lobe rounded and covered with thick setae; outer lobe rounded, twice as wide as inner lobe, covered with thin setae. Maxilliped (Fig. 12E) basis with fringe of thin setae on distal outer margin; palp with one strong seta on proximal article; endite subrectangular, medial seta surpassing distal margin, distal margin covered with thin setae and bearing one seta on outer portion, rostral surface with setose sulcus ending with one short penicil.

Pereopods. Pereopod 1 carpus with short, transverse antennal grooming brush; dactylus with two claws, dactylar seta simple, not surpassing outer claw, ungual seta simple, surpassing outer claw.

UROPOD. Protopod flattened and enlarged, filling gap between pleonite 5 and telson; exopod inserted on median margin, endopod twice as long as exopod and inserted proximally (Fig. 12F).

PleOPOD EXOPODS. Pleopods 1 and 2 with respiratory areas.

\section{Male}

PEREOPOD 1. Merus and carpus with sternal margin covered with short scales and sparse strong setae (Fig. 13A). 
PEREOPOD 7. Ischium elongated, sternal margin straight; carpus twice as long as merus (Fig. 13B).

GENITAL PAPILLA. Bearing triangular ventral shield, papilla slightly longer than ventral shield bearing two subapical orifices (Fig. 13C).

Pleopods. Pleopod 1 (Fig. 13D) exopod heart-shaped; endopod twice as long as exopod, distal portion bent outwards and bearing small setae on median margin. Pleopod 2 (Fig. 13E) exopod triangular, outer margin concave; endopod flagelliform, longer than exopod. Exopods of pleopods 3 and 4 as in Fig. 13F and G, respectively. Pleopod 5 exopod (Fig. 13H) triangular, outer margin sinuous, distal portion elongated, inner margin grooved to accommodate pleopod 2 endopod.

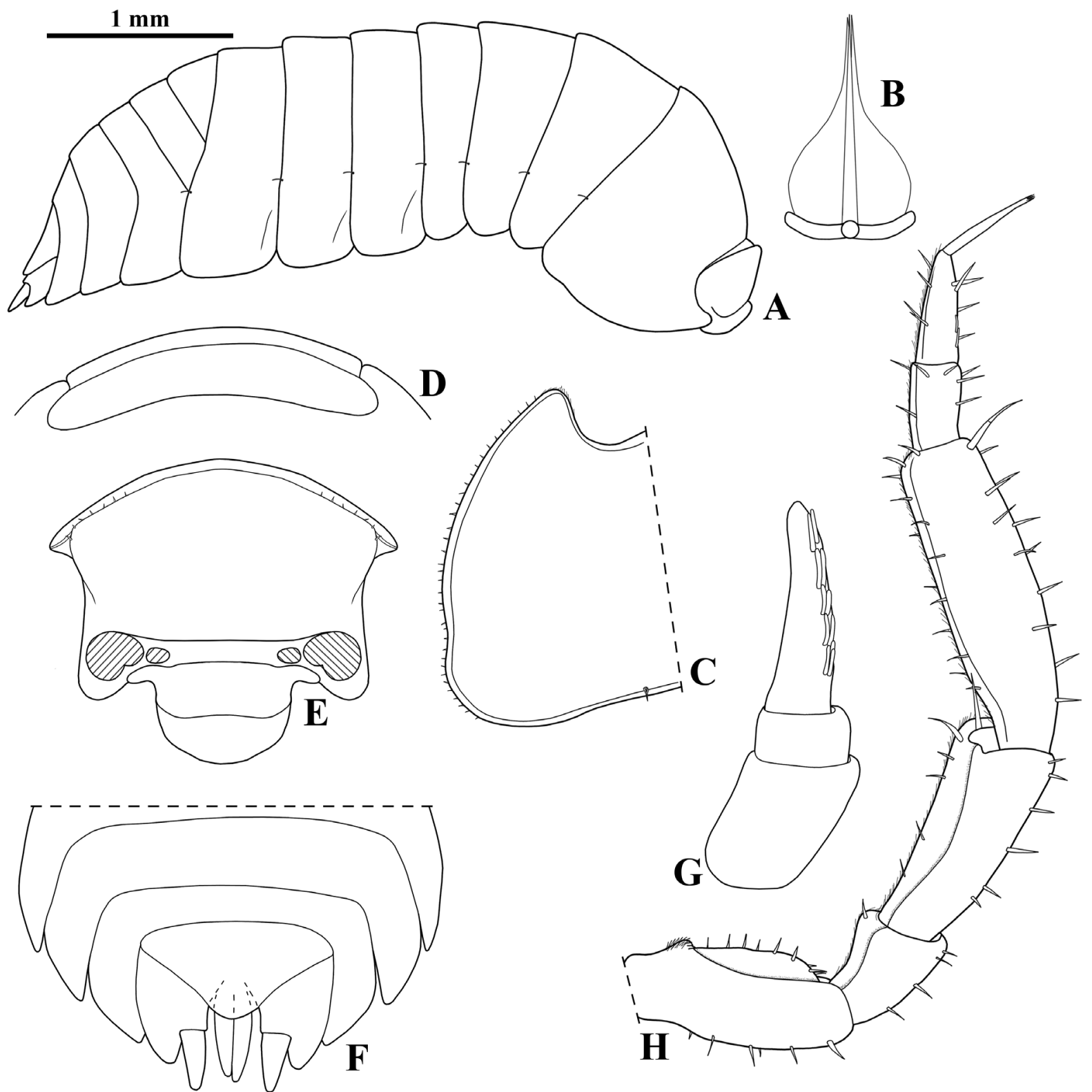

Fig. 11. Amazoniscus spica Campos-Filho, Aguiar \& Taiti sp. nov., + , paratype (MZUSP 40047). A. Habitus, dorsal view. B. Dorsal scale-seta. C. Pereonite 1 epimeron, dorsal view. D. Cephalon and pereonite 1, back view. E. Cephalon, frontal view. F. Pleonites 3-5, telson and uropods. G. Antennula. H. Antenna. 


\section{Remarks}

The genus Amazoniscus comprises five species from Brazil: A. arlei Lemos de Castro, 1967 from the states of Amapá, Pará, Rio de Janeiro and Tocantins; A. eleonorae Souza et al., 2006, A. leistikowi Campos-Filho, Araujo \& Taiti, 2014 and A. zimmeri Campos-Filho, Montesanto \& Araujo, 2017 from the state of Pará; and A. schmidti Campos-Filho, Montesanto \& Araujo, 2017 from the state of Minas Gerais (Souza et al. 2006; Campos-Filho et al. 2014, 2017a, 2018a). The genus is defined by having exoantennal or endoantennal conglobation, the cephalon with a frontal shield delimited superiorly by the frontal line and having a suprantennal line, pereonite 1 epimera without schisma, the antennal flagellum with two articles, the uropod protopod surpassing the telson and the male pleopod 1 exopod heart-shaped (Schmidt 2007; Campos-Filho et al. 2014).

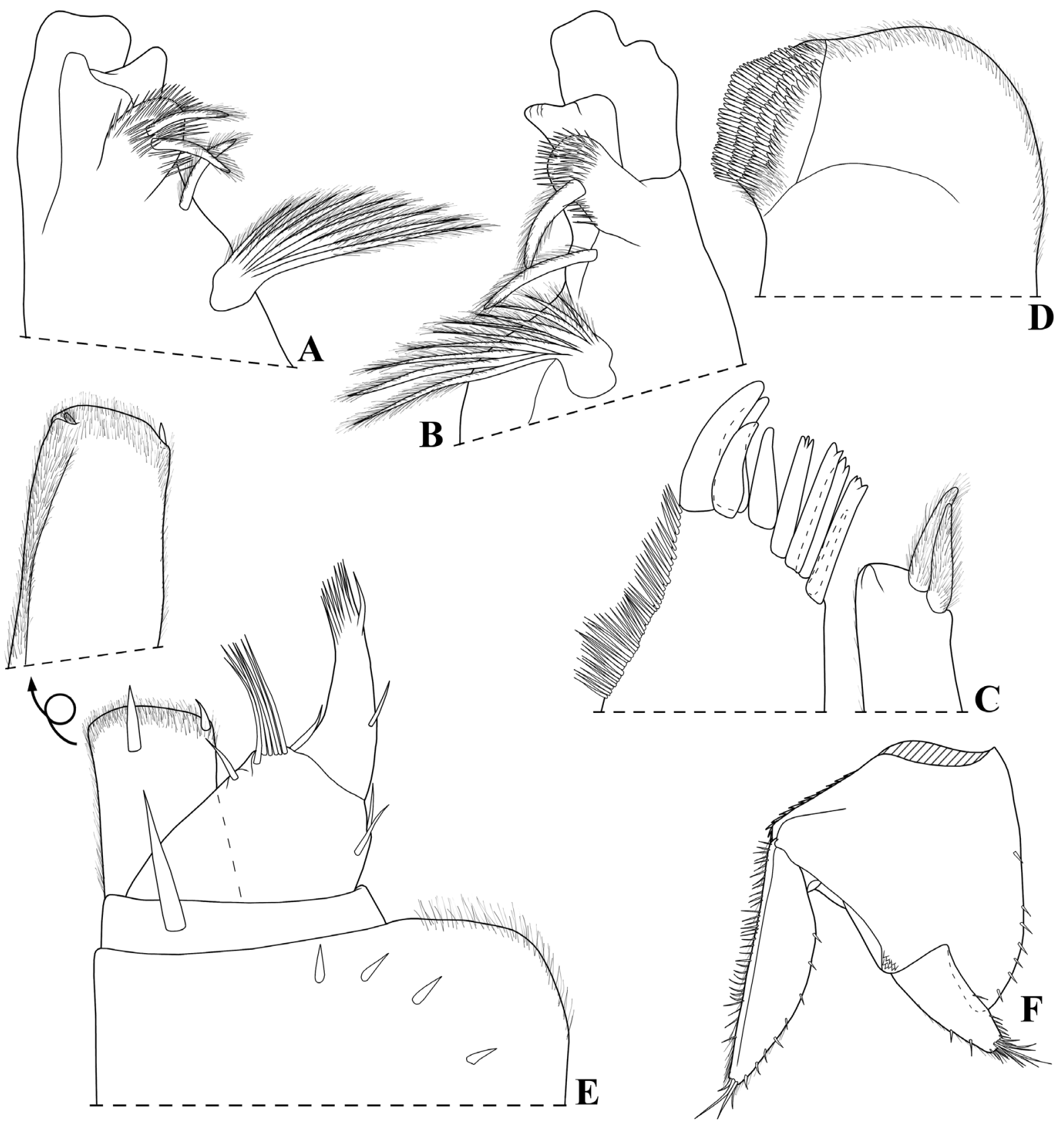

Fig. 12. Amazoniscus spica Campos-Filho, Aguiar \& Taiti sp. nov., $q$, paratype (MZUSP 40047). A. Left mandible. B. Right mandible. C. Maxillula. D. Maxilla. E. Maxilliped. F. Uropod. 
In lacking eyes and body pigment, and in having endoantennal conglobation, Amazoniscus spica sp. nov. is similar to A. eleonorae and A. leistikowi; it differs from both in the shape of the exopod of the male pleopods 1 and 5 (for comparisons, see Souza et al. 2006: figs 1-19 and Campos-Filho et al. 2014: figs 23-25). This species is considered here as troglobiotic.

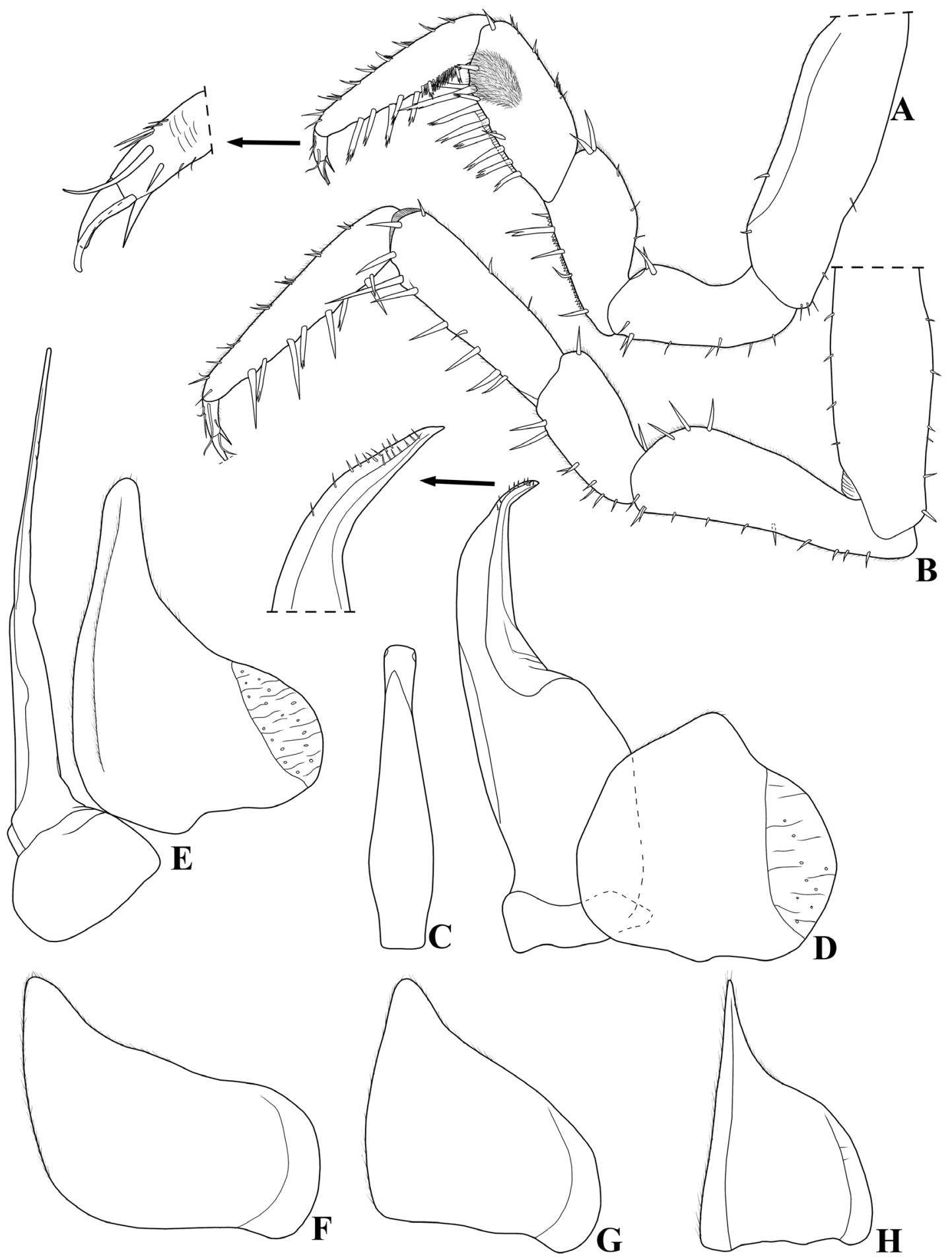

Fig. 13. Amazoniscus spica Campos-Filho, Aguiar \& Taiti sp. nov., $\widehat{\jmath}$, paratype (MZUSP 40047). A. Pereopod 1. B. Pereopod 7. C. Genital papilla. D. Pleopod 1. E. Pleopod 2. F. Pleopod 3 exopod. G. Pleopod 4 exopod. H. Pleopod 5 exopod. 
Genus Circoniscus Pearse, 1917

\section{Type species}

Circoniscus gaigei Pearse, 1917, by monotypy.

Circoniscus bezzii Arcangeli, 1931

Fig. 14

Circoniscus bezzii Arcangeli, 1931: 115, pl. 2.

Circoniscus bezzii - Van Name 1936: 311, fig. 184. - Vilela et al. 1971: 185. - Souza \& Lemos de Castro 1991: 50, figs 23-44. — Schultz 1995: 417, fig. 12j-m. — Souza-Kury 1998: 666. Leistikow \& Wägele 1999: 38. - Schmalfuss 2003: 81. — Schmidt 2007: 72, figs 224-229. Campos-Filho et al. 2014: 396, fig. 40, tables 1-2; 2018a: 17. - Zimmermann et al. 2015b: 3, fig. 2, tables 1-2. — Fernandes et al. 2019: 1109, table 1.

\section{Material examined}

BRAZIL - Minas Gerais State, Presidente Olegário • 1 q; Vereda da Palha; $18^{\circ} 15^{\prime} 18^{\prime \prime}$ S, 46 $46^{\circ} 7^{\prime} 33^{\prime \prime}$ W; Jan. 2014; L.P.A. Resende and T. Zepon leg.; LES 18863 • 1 ô, 1 q; Lapa Zé de Sidnei; $18^{\circ} 18^{\prime} 05.62^{\prime \prime}$ S, $46^{\circ} 05^{\prime} 40.63^{\prime \prime} \mathrm{W}$; Jan. 2014; L.P.A. Resende and T.Zepon leg.; LES 18864 • 1 + ; Arco da Lapa; $18^{\circ} 11^{\prime} 05^{\prime \prime}$ S, 4609'39" W; Sep. 2013; M.E. Bichuette, L.P.A. Resende, T. Zepon and I.A. Ribeiro leg.; LES 18865 Minas Gerais State, Pains • 1 ○े; SM-AM-004; 24 Jul. 2014; T. Santos \& N.T. Pimentel leg.; LES $5474 \bullet$ 1 ○; S1-AM-027/029; 17 Feb. 2014; M. Barcelos and N.T. Pimentel leg.; LES 5475.

\section{Distribution}

This species is known from the Brazilian states of Espírito Santo, Mato Grosso, Minas Gerais and São Paulo, and doubtfully from Paraguay (Campos-Filho et al. 2018a; Fernandes et al. 2019). It has previously been recorded from the Caverna Vereda da Palha cave, Presidente Olegário, Minas Gerais State (Campos-Filho et al. 2014). The present records enlarge our knowledge of its distribution in the subterranean environment of the state of Minas Gerais.

\section{Discussion}

The diversity of the subterranean Oniscidea from Brazilian caves has been recorded in many contributions (e.g., Souza et al. 2006, 2010, 2015; Ferreira et al. 2010, 2015; Campos-Filho \& Araujo 2011; CamposFilho et al. 2014, 2015b, 2016, 2017b, 2017c, 2019; Gallão \& Bichuette 2015, 2018; Silva \& Ferreira 2015; Pellegrini \& Ferreira 2016; Trajano et al. 2016; Bastos-Pereira et al. 2017; Fernandes et al. 2018, 2019; Bichuette et al. 2019). However, the taxonomic impediment is still a major consequence of a delay in the recognition of this fauna, considering that taxonomists that are still active are overloaded and/or face current bureaucratic obstacles, hindering the advance of this knowledge (Ebach et al. 2011; Campos-Filho et al. 2014; Coleman 2015).

Brazil is considered one of the most diverse countries in the world, comprising several ecosystems and biogeographic units (Olson et al. 2001; Morrone 2014), that are considered to be priorities for conservation (Myers et al. 2000; Mittermeier et al. 2005; Bini et al. 2006). The Brazilian subterranean environments are inserted in high diversity areas, e.g., the Bambuí karst region in Cerrado, the Carajás Formation in the Amazon Forest and the Açungui Group in the Atlantic Rainforest (Fig. 14) (CECAV 2015). Recently, some cave systems in the Cerrado, Caatinga and Atlantic Rainforest domains were recognized as hot spots of subterranean fauna in South America (Trajano et al. 2016). However, the Brazilian conservation units (see SNIF 2018) only protect some karst areas (partially showed in Fig. 14), and these environments have been suffering as a consequence of different threats, e.g., mining, 


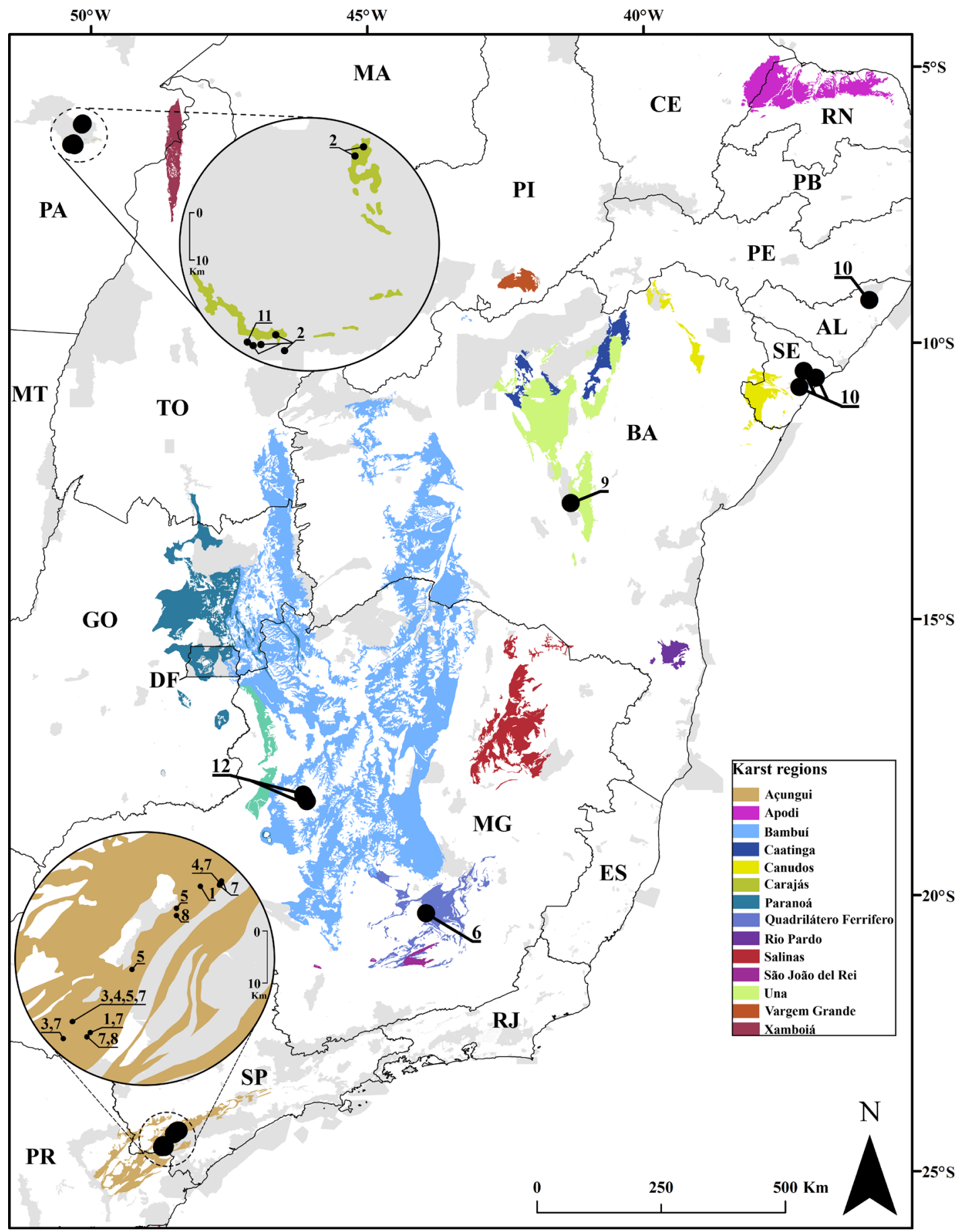

Fig. 14. Distribution map. 1. Alboscia jotajota Campos-Filho, Bichuette \& Taiti sp. nov. 2. Androdeloscia akuanduba Campos-Filho, Cardoso \& Taiti sp nov. 3. Atlantoscia inflata Campos-Filho \& Araujo, 2015. 4. Benthana iporangensis Lima \& Serejo, 1993. 5. B. longicornis Verhoeff, 1941. 6. B. olfersii (Brandt, 1833). 7. B. picta (Brandt, 1833). 8. B. taeniata Araujo \& Buckup, 1994. 9. Metaprosekia igatuensis Campos-Filho, Fernandes \& Bichuette sp. nov. 10. Paratlantoscia rubromarginata (Araujo \& Leistikow, 1999). 11. Amazoniscus spica Campos-Filho, Aguiar \& Taiti sp. nov. 12. Circoniscus bezzii Arcangeli, 1931. Light gray areas denote Brazilian conservation units. $\mathrm{AL}=$ Alagoas; $\mathrm{BA}=$ Bahia; $\mathrm{CE}=$ Ceará; $\mathrm{DF}=$ Distrito Federal; ES = Espírito Santo; GO = Goiás; MA = Maranhão; MG = Minas Gerais; $\mathrm{MT}=$ Mato Grosso PA = Pará; $\mathrm{PB}=$ Paraíba; $\mathrm{PE}=$ Pernambuco PI $=$ Piauí; $\mathrm{PR}=$ Paraná; $\mathrm{RJ}=$ Rio de Janeiro; $\mathrm{RN}=$ Rio Grande do Norte; $\mathrm{SE}=$ Sergipe; $\mathrm{SP}=\mathrm{São}$ Paulo; $\mathrm{TO}=$ Tocantins. 
deforestation, agriculture and pollution of subterranean drainages (Gallão \& Bichuette 2018). It is reasonable to suppose that the subterranean fauna and its environments suffer the consequences of these impacts, which directly modify the microclimate and the quality and quantity of food sources. These impacts may well change the composition of the fauna, leading to extinctions and to the compromise of ecological processes. It is worth mentioning that Brazilian legislation (BRAZIL 1990, 2008) guarantees integral protection to a cave in the presence of one of the attributes that classify it with the maximum degree of relevance, such as the presence of troglobiotic species.

It is clear that this delay in increasing our knowledge of the biodiversity, allied with current threats to the Brazilian subterranean environment, could result in an irreversible loss of this biodiversity. Further planning efforts are extremely necessary for the conservation of both the subterranean and surrounding environments, ensuring the stability of communities inside and outside the caves.

\section{Acknowledgements}

We are grateful to J.E. Gallão, D.M. von Schimonsky, J.S. Gallo and T. Zepon for help during the field trips and collections of MEB's projects; to J.E. Gallão for permission to use his photos (Fig. 1A, C); to Fundação de Amparo à Pesquisa do Estado de São Paulo for grants to the projects of MEB (FAPESP 2008/05678-7 and 2010/08459-4); to Conselho Nacional de Desenvolvimento Científico e Tecnológico for providing a productivity research fellowship to MEB (CNPq 303715/2011-1, 308557/2014-0 and 310378/2017-6); to Instituto Chico Mendes de Conservação da Biodiversidade (ICMBIO, SISBIO processes 28992 and 20165); and to Secretaria de Meio Ambiente, Recursos Hídricos, Infraestrutura, Cidades e Assuntos Metropolitanos (SECIMA) and Fundação Florestal (FF) for facilitating collecting permissions to MEB. This study was financed in part by CAPES (Coordenação de Aperfeiçoamento de Pessoal de Nível Superior, Finance Code 001) and a PNPD scholarship to ISC-F (CAPES/PNPD/ UFCG/CTRN/PPGRN/201713705-5).

\section{References}

Ab'Saber A.N. 1977. Os domínios morfoclimáticos na América do Sul. Primeira aproximação. Geomorfologia 52: 1-21.

Alvares C.A., Stape J.L., Sentelhas P.C., Gonçalves J.L.M. \& Sparovek G. 2013. Köppen's climate classification map for Brazil. Meteorologische Zeitschrift 22 (6): 711-728.

https://doi.org/10.1127/0941-2948/2013/0507

Andersson A. 1960a. South American terrestrial isopods in the collection of the Swedish State Museum of Natural History. Arkiv för Zoologi 12: 537-570.

Andersson A. 1960b. A case of intersexuality in Benthana longicornis Verhoeff (Oniscidae). Arkiv för Zoologi 12: 415-419.

Araujo P.B. 1999. Two new species of Alboscia Schultz, 1995 from Rio Grande do Sul, Brazil (Isopoda, Oniscidea, Philosciidae). Crustaceana 72 (5): 487-496. https://doi.org/10.1163/156854099503537

Araujo P.B. \& Buckup L. 1994. Two new species of terrestrial Isopoda from southern Brazil (Crustacea, Isopoda, Oniscidea). Spixiana 17 (3): 269-274. Available from https://biodiversitylibrary.org/page/28201555 [accessed 7 Feb. 2020].

Araujo P.B. \& Leistikow A. 1999. Philosciids with pleopodal lungs from Brazil, with description of a new species (Crustacea, Isopoda). Contributions to Zoology 68: 109-141. https://doi.org/10.1163/18759866-06802004

Araujo P.B. \& Quadros A.F. 2005. Anew species of Alboscia Schultz, 1995 (Crustacea: Isopoda: Oniscidea: Philosciidae) from Brazil. Zootaxa 1018 (1): 55-60. https://doi.org/10.11646/zootaxa.1018.1.4 
Araujo P.B., Buckup L. \& Bond-Buckup G. 1996. Isópodos terrestres (Crustacea, Oniscidea) de Santa Catarina e Rio Grande do Sul, Brasil. Iheringia, Série Zoologia 81: 111-134. Available from https://archive.org/details/biostor-80146 [accessed on 15 Sep. 2019].

Arcangeli A. 1931. Circoniscus bezzii Arc., nuova specie di isopodo terrestre del Brasile. Bollettino di Zoologia 11: 115-122.

Auler A.S. 2002. Karst areas in Brazil and the potential for major caves - an overview. Boletin de la Sociedad Venezolana de Espeleología 36: 29-35.

Auler A.S. 2004. South America. In: Gunn J. (ed.) Encyclopedia of Cave and Karst Science: 53-57. Taylor and Francis, New York.

Auler A.S. 2017. Hypogene caves and karst of South America. In: Klimchouk A., Palmer A.N., Waele J.D., Auler A.S. \& Andra P. (eds) Hypogene Karst Regions and Caves of the World. Cave and Karst Systems of the World: 817-826. Springer, Cham, Switzerland.

https://doi.org/10.1007/978-3-319-53348-3_55

Auler A.S., Rubbioli E.L. \& Brandi R. 2001. As grandes Cavernas do Brasil. Grupo Bambuí de Pesquisas Espeleológicas, Brazil.

Barreto E.A.S., Almeida E.A.B., Rodrigues V.P.A., Araújo W.V., Silva E.J. \& Mello L.H.C. 2005. Levantamento espeleológico do Estado de Sergipe: diagnóstico preliminar do município de Laranjeiras. In: Rasteiro M.A., Evisel E.M., Benatti R. \& Costa A. (eds) Anais do $28^{\circ}$ Congresso Brasileiro de Espeleologia: 168-174. Sociedade Brasileira de Espeleologia, Campinas. Available from http://www.sbe.com.br/anais28cbe/28cbe_r_168-174.pdf [accessed 6 Feb. 2020].

Bastos-Pereira R., Souza L.A. \& Ferreira R.L. 2017. A new amphibious troglobitic styloniscid from Brazil (Isopoda, Oniscidea, Synocheta). Zootaxa 4294 (2): 292-300.

https://doi.org/10.11646/zootaxa.4294.2.11

Bichuette M.E., Fonseca-Ferreira R. \& Gallão J.E. 2015. Biota associada às cavernas em formações ferríferas. In: Ruchkys U.A., Travassos L.E.P., Rasteiro M.A. \& Faria L.E. (eds) Patrimônio espeleológico em Rochas ferruginosas - Propostas para sua Conservação no Quadrilátero ferrifero, Minas Gerais: 174-191. Sociedade Brasileira de Espeleologia, Campinas, Brazil.

Bichuette M.E., Simões L.B., Zepon T., von Schimonsky D.M. \& Gallão J.E. 2019. Richness and taxonomic distinctness of cave invertebrates from the northeastern state of Goiás, central Brazil: a vulnerable and singular area. Subterranean Biology 29: 1-33. https://doi.org/10.3897/subtbiol.29.30418

Bini L.M., Diniz-Filho J.A.F., Rangel T.F.L.V.B., Basto R.P. \& Pinto M.P. 2006. Challenging Wallacean and Linnean shortfalls: knowledge gradients and conservation planning in a biodiversity hotspot. Diversity and Distributions 12 (5): 475-482. https://doi.org/10.1111/j.1366-9516.2006.00286.x

Brandt J.F. 1833. Conspectus Monographiae Crustaceorum Oniscodorum Latreillii. Byulleten Moskovskogo Obshchestva Ispŷtateleŭ Prirodŷ 6: 171-193.

BRASIL. 1990. Decreto-Lei n ${ }^{\circ} 99.556$, de $1^{\circ}$ de outubro de 1990. Dispõe sobre a proteção das cavidades naturais subterrâneas existentes no território nacional, e dá outras providências. Diário Oficial [da República Federatica do Brasil], Brasília. Available from http://www.planalto.gov.br/ccivil_03/decreto/1990-1994/D99556.htm [accessed 2 Apr. 2019].

BRASIL. 2008. Decreto-Lei n ${ }^{\circ}$. 6640, de 7 de novembro de 2008. Dá nova redação aos arts. $1^{\circ}, 2^{\circ}$, $3^{\circ}, 4^{\circ}$ e $5^{\circ}$ e acrescentaos arts. 5-A e 5-B ao Decreto no 99.556 , de $1^{\circ}$ de outubro de 1990 , que dispõe sobre a proteção das cavidades naturais subterrâneas existentes no território nacional. Diário Oficial [da República Federatica do Brasil], Brasília. Available from http://www.planalto.gov.br/ccivil_03/_Ato2007-2010/2008/Decreto/D6640.htm [accessed 2 Apr. 2019]. 
Campos J.F. \& Castilho A.F. 2012. Uma visão geográfica da região da Flona de Carajás. In: Martins F.D., Castilho A.F., Campos J.F., Hatano F.M. \& Rolim S.G. (eds) Fauna da Floresta nacional de Carajás: Estudos sobre Vertebrados terrestres: 16-27. Nitro Imagens, São Paulo.

Campos-Filho I.S. \& Araujo P.B. 2011. Two new troglobitic species of Scleropactidae(Crustacea: Isopoda: Oniscidea) from Pará, Brazil. Nauplius 19: 27-39. https://doi.org/10.1590/S0104-64972011000100004

Campos-Filho I.S., Contreira S.G. \& Lopes-Leitzke E.R. 2012. A new species of Atlantoscia Ferrara \& Taiti, 1981 (Oniscidea: Philosciidae) from Rio Grande do Sul, Brazil. Nauplius 20: 138-144. https://doi.org/10.1590/S0104-64972012000200006

Campos-Filho I.S., Lisboa J.T. \& Araujo P.B. 2013. Review of Atlantoscia Ferrara \& Taiti, 1981 (Crustacea: Isopoda: Oniscidea: Philosciidae) with new records and new species. Organisms, Diversity \& Evolution 13: 463-483. https://doi.org/10.1007/s13127-013-0124-8

Campos-Filho I.S., Araujo P.B., Bichuette M.E., Trajano E. \& Taiti S. 2014. Terrestrial isopods (Crustacea: Isopoda: Oniscidea) from Brazilian caves. Zoological Journal of the Linnean Society 172 (2): 360-425. https://doi.org/10.1111/zoj.12172

Campos-Filho I.S., Taiti S. \& Araujo P.B. 2015a. Taxonomic revision of the genus Benthana BuddeLund, 1908 (Isopoda: Oniscidea: Philosciidae). Zootaxa 4022 (1): 1-73.

https://doi.org/10.11646/zootaxa.4022.1.1

Campos-Filho I.S., Mise K.M. \& Sessegolo G.C. 2015b. A new species of Trichorhina Budde-Lund, 1908 (Isopoda: Oniscidea: Platyarthridae) from Paraná caves, southern Brazil. Nauplius 23: 112-119. https://doi.org/10.1590/S0104-64972015002324

Campos-Filho I.S., Bichuette M.E. \& Taiti S. 2016. Three new species of terrestrial isopods (Crustacea, Isopoda, Oniscidea) from Brazilian caves. Nauplius 24: e2016001.

https://doi.org/10.1590/2358-2936e2016001

Campos-Filho I.S., Montesanto G., Araujo P.B. \& Taiti S. 2017a. New species and new records of terrestrial isopods (Crustacea, Isopoda, Oniscidea) from Brazil. Iheringia, Série Zoologia 107: e2017034. https://doi.org/10.1590/1678-4766e2017034

Campos-Filho I.S., Bichuette M.E., Montesanto G., Araujo P.B. \& Taiti S. 2017b. The first troglobiotic species of the family Pudeoniscidae (Crustacea, Isopoda, Oniscidea), with descriptions of a new genus and two new species. Subterranean Biology 23: 69-84. https://doi.org/10.3897/subtbiol.23.20963

Campos-Filho I.S., Bichuette M.E., Araujo P.B. \& Taiti S. 2017c. Description of a new species of Cylindroniscus Arcangeli, 1929 (Isopoda: Oniscidea) from Brazil, with considerations on the family placement of the genus. North-Western Journal of Zoology 13 (2): e161305. Available from https://biozoojournals.ro/nwjz/content/v13n2/nwjz_e161305_Campos.pdf [accessed 6 Feb. 2020].

Campos-Filho I.S., Cardoso G.M. \& Aguiar J.O. 2018a. Catalogue of terrestrial isopods (Crustacea, Isopoda, Oniscidea) from Brazil: an update with some considerations. Nauplius 26: e2018038. https://doi.org/10.1590/2358-2936e2018038

Campos-Filho I.S., Cardoso G.M. \& Aguiar J.O. 2018b. A new species of Novamundoniscus Schultz, 1995 (Isopoda, Oniscidea, Dubioniscidae) from the state of Tocantins, Brazil. Papéis Avulsos de Zoologia 58: e20185860. https://doi.org/10.11606/1807-0205/2018.58.60

Campos-Filho I.S., Fernandes C.S., Cardoso G.M., Bichuette M.E., Aguiar J.O. \& Taiti S. 2019. Two new species and new records of terrestrial isopods (Crustacea, Isopoda, Oniscidea) from Brazilian caves. Zootaxa 4564 (2): 422-448. https://doi.org/10.11646/zootaxa.4564.2.6 
Carpio-Díaz Y.M., López-Orozco C.M., Campos-Filho I.S. \& Navas S.G.R. 2018. Terrestrial isopods (Isopoda: Oniscidea) of the Botanical Garden of Cartagena "Guillermo Piñeres", Colombia, with the description of three new species. Arthropoda Selecta 27 (4): 301-318.

https://doi.org/10.15298/arthsel.27.4.05

Cavalcanti L.F. 2017. Dados secundários de espécies classificadas como troglóbias e troglomórficas para o projeto áreas prioritárias para a conservação do patrimônio espeleológico brasileiro. In: Rasteiro M.A., Teixeira-Silva C.M. \& Lacerda S.G. (eds) Anais do $34^{\circ}$ Congresso Brasileiro de Espeleologia: 43-66. Sociedade Brasileira de Espeleologia, Campinas, Brazil. Available from http://www.cavernas.org.br/anais34cbe/34cbe_043-066.pdf [accessed on 15 Sep. 2019].

CECAV - Centro Nacional de Pesquisa e Conservação de Cavernas. 2015. Base de Dados eoespacializados das Cavernas do Brasil. Available from http://www.icmbio.gov.br/cecav/downloads/mapas.html [accessed on 11 Nov. 2018].

Coleman C.O. 2015. Taxonomy in times of the taxonomic impediment - Examples from the community of experts on amphipod crustaceans. Journal of Crustacean Biology 25 (6): 729-740.

https://doi.org/10.1163/1937240X-00002381

Costa M.J.R., Silva D.C.C. \& Bichuette M.E. 2015. Levantamento preliminar da fauna cavernícola de Sergipe. In: Rasteiro M.A. \& Sallun Filho W. (eds) Anais do $33^{\circ}$ Congresso Brasileiro de Espeleologia: 127-133. Sociedade Brasileira de Espeleologia, Campinas. Available from http://www.cavernas.org.br/anais33cbe/33cbe_127-133.pdf [accessed 6 Feb. 2020].

Costa S.L.N., Campos-Filho I.S. \& Araujo P.B. 2014. New species and new records of Benthana BuddeLund, 1908 (Isopoda: Oniscidea: Philosciidae) from southern Brazil. Papéis Avulsos de Zoologia 54: 169-176. https://doi.org/10.1590/0031-1049.2014.54.13

Crescencio G. \& Carmo P.L. 2013. Cavernas, mineração e comunidades da Amazônia: a caverna Labirinto de Máfica e o caso da Vila na Racha Placa em Canaã dos Carajás/PA. In: Rasteiro M.A. \& Morato L. (eds) Anais do $32^{\circ}$ Congresso Brasileiro de Espeleologia: 167-173. Sociedade Brasileira de Espeleologia, Campinas. Available from http://www.cavernas.org.br/anais32cbe/32cbe_167-173.pdf [accessed on 15 Nov.2018].

Ebach M.C., Valdecasas A.G. \& Wheeler Q.D. 2011. Impediments to taxonomy and users of taxonomy: accessibility and impact evaluation. Cladistics 27: 550-557.

https://doi.org/10.1111/j.1096-0031.2011.00348.x

Fernandes C.S., Campos-Filho I.S. \& Bichuette M.E. 2018. Cylindroniscus platoi (Isopoda: Oniscidea: Styloniscidae), a new cave-dwelling species from Lagoa Santa Karst, Southeasthern Brazil. Zootaxa 4461 (3): 411-420. https://doi.org/10.11646/zootaxa.4464.3.6

Fernandes C.S., Campos-Filho I.S., Araujo P.B. \& Bichuette M.E. 2019. Synopsis of terrestrial isopods (Crustacea: Isopoda: Oniscidea) from Brazilian caves, with emphasis on new records from north, midwest, northeast and southeast regions. Journal of Natural History 53 (17-18): 1095-1129. https://doi.org/10.1080/00222933.2019.1634225

Ferreira R.L., Prous X., Bernardi L.F.O. \& Souza-Silva M. 2010. Fauna subterrânea do estado do Rio Grande do Norte: caracterização e impactos. Revista Brasileira de Espeleologia 1: 25-51.

Ferreira R.L., Oliveira M.P.A. \& Silva M.S. 2015. Biodiversidade subterrânea em geossistemas ferruginosos. In: Carmo F.F.C. \& Kamino L.H.Y. (eds) Geossistemas ferruginosos do Brasil: Áreas prioritárias para Conservação da Diversidade geológica e biológica, Patrimônio cultural e Serviços ambientais. 3i Editora, Belo Horizonte, Brazil. 
Gallão J.E. \& Bichuette M.E. 2012. A lista de fauna ameaçada de extinção e os entraves para a inclusão de espécies - o exemplo dos peixes troglóbios brasileiros. Natureza \& Conservação 10: 83-87.

https://doi.org/10.4322/natcon.2012.014

Gallão J.E. \& Bichuette M.E. 2015. Taxonomic distinctness and conservation of a new high biodiversity subterranean area in Brazil. Anais da Academia Brasileira de Ciências 87 (1): 209-217.

https://doi.org/10.1590/0001-3765201520140312

Gallão J.E. \& Bichuette M.E. 2018. Brazilian obligatory subterranean fauna and threats to the hypogean environment. ZooKeys 746: 1-23. https://doi.org/10.3897/zookeys.746.15140

Grangeiro D.C. \& Christoffersen M.L. 2010. A new species of Androdeloscia (Isopoda: Philosciidae) from the Brazilian Amazon. Revista Nordestina de Biologia 19 (2): 77-93.

Grangeiro D.C. \& Souza L.A. 2006. First record of terrestrial crustaceans (Isopoda, Oniscidea) from Chapada do Araripe, Ceará state, Brazil. Cadernos de Cultura e Ciência 1: 33-39.

Gruner H.E. 1955. Die Gattung Benthana Budde-Lund, 1908 (Isopoda, Oniscoidea). Zoologische Jahrbücher, Abteilung für Systematik, Ökologie und Geographie der Tiere 83: 441-452.

Hornung E. 2011. Evolutionary adaptation of oniscidean isopods to terrestrial life: structure, physiology and behavior. Terrestrial Arthropod Reviews 4: 95-130. https://doi.org/10.1163/187498311X576262

Javidkar M., Cooper S.J.B., King R.A., Humphreys W.F. \& Austin A. 2015. Molecular phylogenetic analyses reveal a new southern hemisphere oniscidean family (Crustacea: Isopoda) with a unique water transport system. Invertebrate Systematics 29: 554-577. https://doi.org/10.1071/IS15010

Karmann I. \& Sánchez L.E. 1979. Distribuição das rochas carbonáticas e províncias espeleológicas do Brasil. Espeleo-Tema 13: 105-167.

Leistikow A. 1997. Terrestrial isopods from Costa Rica and a redescription of Ischioscia variegata (Dollfus, 1893) (Crustacea: Isopoda: Oniscidea). Canadian Journal of Zoology 75 (9): 1415-1464. https://doi.org/10.1139/z97-768

Leistikow A. 1999. Androdeloscia gen. n., a new genus of South American terrestrial isopods with description of 13 new species (Crustacea: Oniscidae: "Philosciidae"). Revue Suisse de Zoologie 106: 813-904. Available from https://biodiversitylibrary.org/page/41279890 [accessed 7 Feb. 2020].

Leistikow A. 2000. A new genus of Oniscidea from South America and a phylogenetic analysis of related genera (Crustacea: Isopoda: Philosciidae). Contributions to Zoology 69: 179-196.

https://doi.org/10.1163/18759866-06903003

Leistikow A. 2001. Phylogeny and biogeography of South American Crinocheta, traditionally placed in the family "Philosciidae" (Crustacea: Isopoda: Oniscidea). Organisms, Diversity \& Evolution, Electronic Supplement 4: 1-85. Available from

http://www.senckenberg.uni-frankfurt.de/odes/01-04.htm [accessed 6 Feb. 2020].

Leistikow A. \& Wägele J.W. 1999. Checklist of terrestrial isopods of the New World (Crustacea, Isopoda, Oniscidea). Revista Brasileira de Zoologia 16 (1): 1-72.

Lemos de Castro A. 1958. Revisao do genero Benthana Budde-Lund, 1908 (Isopoda, Oniscidae). Arquivos do Museu Nacional 44: 85-118.

Lima M.I. \& Serejo C.S. 1993. A new species of Benthana Budde-Lund from Brazilian caves (Crustacea; Isopoda; Oniscoidea). Proceedings of the Biological Society of Washington 106 (3): 490-496. Available from https://biodiversitylibrary.org/page/34574322 [accessed 7 Feb. 2020]. 
Lisboa J.T., Couto E.C.G., Santos P.P., Delabie J.H.C. \& Araujo P.B. 2013. Terrestrial isopods (Crustacea: Isopoda: Oniscidea) in termite nests (Blattodea: Termitidae) in a cocoa plantation in Brazil. Biota Neotropica 13 (3): 393-397.

López-Orozco C.M., Carpio-Díaz Y.M., Navas S.G.R.N. \& Campos-Filho I.S. 2016. A new species and first record of Androdeloscia (Oniscidea: Philosciidae) from Colombia. Studies on Neotropical Fauna and Environment 52: 18-24. https://doi.org/10.1080/01650521.2016.1254861

López-Orozco C.M., Carpio-Díaz Y.M., Navas S.G.R.N. \& Campos-Filho I.S. 2017. A new species and first record of Pulmoniscus Leistikow, 2001 (Isopoda, Oniscidea, Philosciidae) from Colombia. Nauplius 25: e2017014. https://doi.org/10.1590/2358-2936e2017014

Macedo H.S., Araújo H.M., Donato C.R., Bezerra G.S. \& Carvalho I.S.M. 2012. Considerações sobre o ambiente cárstico em Sergipe. In: Anais do $9^{\circ}$ Simpósio Nacional de Geomorfologia: 1-4. União da Geomorfologia Brasileira and Universidade Federal do Rio de Janeiro, Rio de Janeiro. Available from http://www.sinageo.org.br/2012/trabalhos/3/3-621-83.pdf [accessed on 23 Dec. 2018].

Mittermeier R.A., Fonseca G.A.B., Rylands A.B. \& Brandon K. 2005. A brief history of biodiversity conservation in Brazil. Conservation Biology 19 (3): 602-607.

https://doi.org/10.1111/j.1523-1739.2005.00709.x

Montesanto G. 2015. A fast GNU method to draw accurate scientific illustrations for taxonomy. ZooKeys 515: 191-206. https://doi.org/10.3897/zookeys.515.9459

Montesanto G. 2016. Drawing setae: a GNU way for digital scientific illustrations. Nauplius 24: e2016017. https://doi.org/10.1590/2358-2936e2016017

Morrone J.J. 2014. Biogeographical regionalisation of the Neotropical region. Zootaxa 3782 (1): 1-110. https://doi.org/10.11646/zootaxa.3782.1.1

Myers N., Mittermeier R.A., Mittermeier C.G., Fonseca G.A.B. \& Kent J. 2000. Biodiversity hotspots for conservation priorities. Nature 403: 853-858. https://doi.org/10.1038/35002501

Olson D.M., Dinerstein E., Wikramanayake E.D., Burgess N.D., Powell G.V.N., Underwood E.C., D'Amico J.A., Itoua I., Strand H.E., Morrison J.C., Loucks C.J., Allnutt T.F., Ricketts T.H., Kura Y., Lamoreux J.F., Wettengel W.W., Hedao P. \& Kassem K.R. 2001. Terrestrial ecoregions of the world: A new map of life on Earth. BioScience 51 (11): 933-938.

https://doi.org/10.1641/0006-3568(2001)051[0933:TEOTWA]2.0.CO;2

Pellegrini T.G. \& Ferreria R.L. 2016. Are inner cave communities more stable than entrance communities in Lapa Nova show cave? Subterranean Biology 20: 15-37. https://doi.org/10.3897/subtbiol.20.9334

Pinto-da-Rocha R. 1995. Sinopse da fauna cavernícola do Brasil (1907-1994). Papéis Avulsos de Zoologia 39: 61-173.

Pires A.C., Parizotto D.R., Mise C.M., Sessegolo G.C. \& Ferreira R.L. 2015. Chave de identificação interativa de múltiplas entradas para as espécies de invertebrados troglóbios do Brasil. In: Rasteiro M.A. \& Sallun Filho W. (eds) Anais do $33^{\circ}$ Congresso Brasileiro de Espeleologia: 65-74. Sociedade Brasileira de Speleologia, Campinas, Brazil. Available from http://www.cavernas.org.br/anais33cbe/33cbe_065-074.pdf [accessed on 15 Sep. 2019].

Reboleira A.S.P.S., Gonçalves F., Oromí P. \& Taiti S. 2015. The cavernicolous Oniscidea (Crustacea: Isopoda) of Portugal. Europena Journal of Taxonomy 161: 1-61. https://doi.org/10.5852/ejt.2015.161

Richardson A. \& Araujo P.B. 2015. Lifestyles of terrestrial crustaceans. In: Thiel M. \& Watling L. (eds) The Natural History of the Crustacea. Lifestyles and Feeding Biology: 299-336. Oxford University Press, Oxford, UK. 
Rubbioli E., Auler A., Menin D. \& Brandi R. 2019. Cavernas-Atlas do Brasil Subterrâneo. ICMBio, Brasília, DF.

Sallun A.E.M. \& Sallun Filho W. 2009. Geologia em planos de manejo - subsídios para zoneamento ambiental do PEI - SP. Geociências 28 (1): 91-107.

Sallun Filho W. \& Karmann I. 2012. Províncias cársticas e cavernas no Brasil. In: Hasui Y., Carneito C.D.R., Almeida F.F.M. \& Bartorelli A. (eds) Geologia do Brasil: 629-641. Ed. Beca, São Paulo.

Schmalfuss H. 1984. Eco-morphological strategies in terrestrial isopods. Proceedings of the Zoological Society of London 53: 49-63.

Schmalfuss H. 2003. World catalog of terrestrial isopods (Isopoda: Oniscidea). Stuttgarter Beiträge zur Naturkunde, Serie A 654: 1-341.

Schmidt C. 2002. Contribution to the phylogenetic system of the Crinocheta (Crustacea, Isopoda). Part 1 (Olibrinidae to Scyphacidae s. str.). Mitteilungen aus dem Zoologischen Museum in Berlin 78: 275-352. https://doi.org/10.1002/mmnz.20020780207

Schmidt C. 2003. Contribution to the phylogenetic system of the Crinocheta (Crustacea, Isopoda). Part 2 (Oniscoidea to Armadillidiidae). Mitteilungen aus dem Zoologischen Museum in Berlin 79: 3-179. https://doi.org/10.1002/mmnz.20030790102

Schmidt C. 2007. Revision of the Neotropical Scleropactidae (Crustacea: Oniscidea). Zoological Journal of the Linnean Society 151: 1-339. https://doi.org/10.1111/j.1096-3642.2007.00286.x

Schmidt C. \& Leistikow A. 2005. Review of the genus Androdeloscia Leistikow, with description of four new species (Crustacea: Isopoda: Oniscidea). Entomologische Abhandlungen 62 (2): 117-163.

Schultz G.A. 1995. Terrestrial isopod crustaceans (Oniscidea) from Paraguay with definition of a new family. Revue Suisse de Zoologie 102 (2): 387-424. https://doi.org/10.5962/bhl.part.80471

SEMA - Secretaria do Meio Ambiente do Estado de São Paulo. 1997. Macrozoneamento do Vale do Ribeira. Proposta preliminar para Discussão pública. São Paulo.

SEMA - Secretaria do Meio Ambiente do Estado de São Paulo. 2006. Áreas especialmente protegidas. São Paulo.

Sfenthourakis S. \& Taiti S. 2015. Patterns of taxonomic diversity among terrestrial isopods. ZooKeys 515: 13-25. https://doi.org/10.3897/zookeys.515.9332

Silva M.S. \& Ferreira R.L. 2015. Cave invertebrates in Espírito Santo state, Brazil: a primary analysis of endemism, threats and conservation priorities. Subterranean Biology 16: 79-102.

https://doi.org/10.3897/subtbiol.16.5227

SNIF - Sistema Nacional de Informações Florestais. 2018. Sistema Nacional de Unidades de Conservação - Mapas. Available from http://snif.florestal.gov.br/pt-br/dados-complementares/212-sistema-nacionalde-unidades-de-conservacao-mapas [accessed on 2 Apr. 2019].

Souza L.A. \& Lemos de Castro A. 1991. The genus Circoniscus Pearse, 1917 in Brazil, with a description of three new species (Isopoda Oniscidea Scleropactidae). Tropical Zoology 4: 45-64.

https://doi.org/10.1080/03946975.1991.10539474

Souza L.A., Bezerra A.V. \& Araújo J.P. 2006. The first troglobitic species of Scleropactidae from Brazil (Crustacea, Isopoda, Oniscidea). Subterranean Biology 4: 37-43.

Souza L.A., Senna A.R. \& Kury A.B. 2010. A new species and first record of Gabunillo Schmalfuss \& Ferrara, 1983 (Isopoda, Oniscidea, Armadillidae) from the Neotropics. Zootaxa 2677 (1): 1-14.

https://doi.org/10.11646/zootaxa.2677.1.1 
Souza L.A., Ferreira R.L. \& Senna A.R. 2015. Amphibious shelter-builder Oniscidea species from the New World with description of a new subfamily, a new genus and a new species from Brazilian Cave (Isopoda, Synocheta, Styloniscidae). PLoS ONE 10 (5): e0115021.

https://doi.org/10.1371/journal.pone.0115021

Souza-Kury L.A. 1998. Malacostraca. Peracarida. Isopoda. Oniscidea. In: Young P. (ed.) Catalogue of Crustacea of Brazil: 653-674. Museu Nacional, Rio de Janeiro.

Taiti S. 2014. New subterranean Armadillidae (Crustacea, Isopoda, Oniscidea) from Western Australia. Tropical Zoology 27 (4): 153-165. https://doi.org/10.1080/03946975.2014.984510

Taiti S. 2018. Biologia e biogeografia degli isopodi terrestri (Crustacea, Isopoda, Oniscidea). Atti dell'Accademia nazionale italiana di Entomologia 65: 83-90.

Taiti S. \& Ferrara F. 1982. Revision of the family Philosciidae (Crustacea, Isopoda, Oniscoidea) from South Africa. Annals of the South African Museum 90: 1-48. Available from

https://biodiversitylibrary.org/page/40763669 [accessed 6 Feb. 2020].

Taiti S. \& Gruber G.A. 2008. Cave-dwelling terrestrial isopods from southern China (Crustacea, Isopoda, Oniscidea), with descriptions of four new species. In: Latella L. \& Zorzin R. (eds) Research in South China Karsts. Memorie del Museo Civico di Storia Naturale di Verona, Monografie Naturalistiche 3: 101-123.

Taiti S. \& Montesanto G. 2018. New species of subterranean and endogean terrestrial isopods (Crustacea, Oniscidea) from Tuscany (central Italy). Zoosystema 40 (11) 197-226.

https://doi.org/10.5252/zoosystema2018v40a11

Taiti S. \& Xue Z. 2012. The cavernicolous genus Trogloniscus nomen novum, with descriptions of four new species from southern China (Crustacea, Oniscidea, Styloniscidae). Tropical Zoology 25: 183-209. https://doi.org/10.1080/03946975.2012.751240

Taiti S., Montesanto G. \& Vargas J.A. 2018. Terrestrial Isopoda (Crustacea, Oniscidea) from the coasts of Costa Rica, with descriptions of three new species. Revista de Biologia Tropical 66 (Suppl. 1): S187S210. https://doi.org/10.15517/RBT.V66I1.33296

Trajano E. \& Bichuette M.E. 2010. Relevância de cavernas: porque estudos ambientais espeleobiológicos não funcionam. Espeleo-Tema 21 (1): 105-112.

Trajano E., Secutti S. \& Bichuette M.E. 2009. Natural history and population data of fishes in caves of the Serra do Ramalho karst area, Middle São Francisco basin, northeastern Brazil. Biota Neotropica 9 (1): 129-133. https://doi.org/10.1590/S1676-06032009000100015

Trajano E., Gallão J.E. \& Bichuette M.E. 2016. Spots of high diversity of troglobites in Brazil: the challenge of measuring subterranean diversity. Biodiversity and Conservation 25 (10): 1805-1828. https://doi.org/10.1007/s10531-016-1151-5

Van Name W. 1936. The American land and freshwater isopod Crustacea. Bulletin of the American Museum of Natural History 71: 1-535.

Vandel A. 1962. Isopodes terrestres (deuxième partie). In: Fédération française des Sociétes de Sciences naturelles (ed.) Faune de France 66: 417-931. P. Lechevalier, Paris.

Verhoeff K.W. 1941. Zur Kenntnis südamerikanischer Oniscoideen. 71. Isopoden-Aufsatz. Zoologischer Anzeiger 133: 114-126.

Vilela E.F., Kudo H. \& Loureiro M. 1971. Oniscoides de Dourados, Estado de Mato Grosso. Seiva 31: 183-189.

WoRMS - World Register of Marine Species. 2019. Oniscidea. Available from

http://www.marinespecies.org/aphia.php?p=taxdetails\&id=146505 [accessed 28 Feb. 2019]. 
Zimmermann B.L., Campos-Filho I.S., Deprá M. \& Araujo P.B. 2015a. Taxonomy and molecular phylogeny of the Neotropical genus Atlantoscia (Oniscidea, Philosciidae): DNA barcoding and description of two new species. Zoological Journal of the Linnean Society 174: 702-717.

https://doi.org/10.1111/zoj.12256

Zimmermann B.L., Bouchon D., Almerão M.P. \& Araujo P.B. 2015b. Wolbachia in Neotropical terrestrial isopods. FEMS Microbiology Ecology 91 (4): efiv025. https://doi.org/10.1093/femsec/fiv025

Zimmermann B.L., Campos-Filho I.S. \& Araujo P.B. 2018a. Integrative taxonomy reveals a new genus and new species of Philosciidae (Crustacea: Isopoda: Oniscidea) from the Neotropical region. Canadian Journal of Zoology 96: 473-485. https://doi.org/10.1139/cjz-2017-0289

Zimmermann B.L., Palaoro A.V., Bouchon D., Almerão M.P. \& Araujo P.B. 2018b. How coexistence may influence life history: the reproduction strategies of sympatric congeneric terrestrial isopods (Crustacea, Oniscidea). Canadian Journal of Zoology 96 (11): 1214-1220. https://doi.org/10.1139/cjz-2018-0086

Manuscript received: 16 September 2019

Manuscript accepted: 25 November 2019

Published on: 20 February 2020

Topic editor: Rudy Jocqué

Desk editor: Danny Eibye-Jacobsen

Printed versions of all papers are also deposited in the libraries of the institutes that are members of the EJT consortium: Muséum national d'histoire naturelle, Paris, France; Meise Botanic Garden, Belgium; Royal Museum for Central Africa, Tervuren, Belgium; Royal Belgian Institute of Natural Sciences, Brussels, Belgium; Natural History Museum of Denmark, Copenhagen, Denmark; Naturalis Biodiversity Center, Leiden, the Netherlands; Museo Nacional de Ciencias Naturales-CSIC, Madrid, Spain; Real Jardín Botánico de Madrid CSIC, Spain; Zoological Research Museum Alexander Koenig, Bonn, Germany; National Museum, Prague, Czech Republic. 